\title{
Preliminary Report on Oak Ridge National Laboratory Testing of Drake/ACSS/MA2/E3X ${ }^{\text {TM }}$
}

Approved for public release. Distribution is unlimited.
Philip Irminger

Dan King Drew Herron Cody Davis Bill Temple Gord Baker Vijay Mhetar Phil Overholt Zhi Li Michael Starke Ben Ollis

December 2015 


\title{
DOCUMENT AVAILABILITY
}

Reports produced after January 1, 1996, are generally available free via US Department of Energy (DOE) SciTech Connect.

\section{Website http://www.osti.gov/scitech/}

Reports produced before January 1, 1996, may be purchased by members of the public from the following source:

\author{
National Technical Information Service \\ 5285 Port Royal Road \\ Springfield, VA 22161 \\ Telephone 703-605-6000 (1-800-553-6847) \\ TDD 703-487-4639 \\ Fax 703-605-6900 \\ E-mailinfo@ntis.gov \\ Website http://www.ntis.gov/help/ordermethods.aspx
}

Reports are available to DOE employees, DOE contractors, Energy Technology Data Exchange representatives, and International Nuclear Information System representatives from the following source:

Office of Scientific and Technical Information

PO Box 62

Oak Ridge, TN 37831

Telephone 865-576-8401

Fax 865-576-5728

E-mail reports@osti.gov

Website http://www.osti.gov/contact.html

This report was prepared as an account of work sponsored by an
agency of the United States Government. Neither the United States
Government nor any agency thereof, nor any of their employees,
makes any warranty, express or implied, or assumes any legal liability
or responsibility for the accuracy, completeness, or usefulness of any
information, apparatus, product, or process disclosed, or represents
that its use would not infringe privately owned rights. Reference herein
to any specific commercial product, process, or service by trade name,
trademark, manufacturer, or otherwise, does not necessarily constitute
or imply its endorsement, recommendation, or favoring by the United
States Government or any agency thereof. The views and opinions of
authors expressed herein do not necessarily state or reflect those of
the United States Government or any agency thereof.


Electrical and Electronics Systems Research Division

\title{
PRELIMINARY REPORT ON OAK RIDGE NATIONAL LABORATORY TESTING OF DRAKE/ACSS/MA2/E3XTM
}

\author{
Philip Irminger \\ Oak Ridge National Laboratory \\ Dan King \\ Oak Ridge National Laboratory \\ Drew Herron \\ Oak Ridge National Laboratory \\ Cody Davis \\ General Cable Corporation \\ Bill Temple \\ General Cable Corporation \\ Gord Baker \\ General Cable Corporation \\ Vijay Mhetar \\ General Cable Corporation \\ Phil Overholt \\ Department of Energy \\ Zhi Li \\ Oak Ridge National Laboratory \\ Michael Starke \\ Oak Ridge National Laboratory \\ Ben Ollis \\ Oak Ridge National Laboratory
}

Date Published: December 2015

Prepared by

OAK RIDGE NATIONAL LABORATORY

Oak Ridge, TN 37831-6283

managed by

UT-BATTELLE, LLC

for the

US DEPARTMENT OF ENERGY

under contract DE-AC05-00OR22725 



\section{CONTENTS}

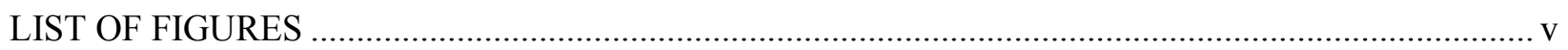

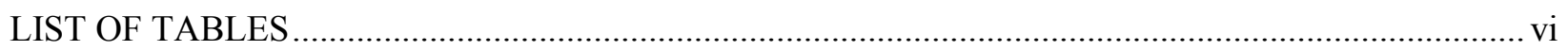

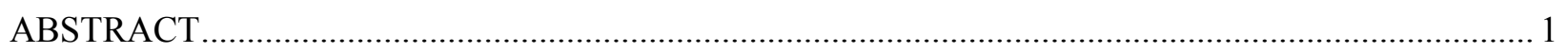

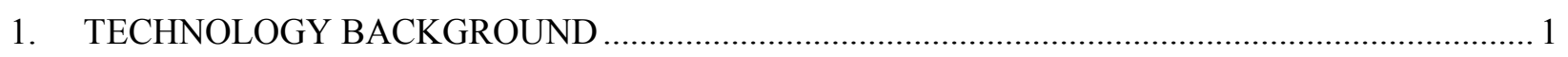

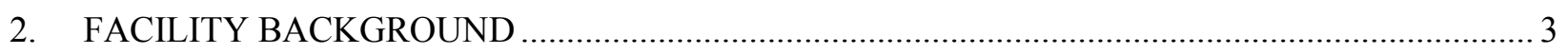

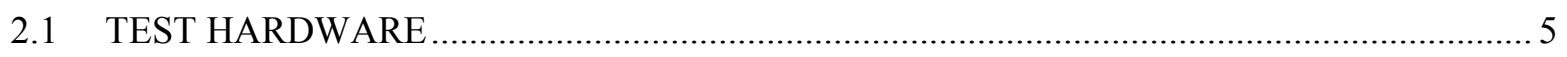

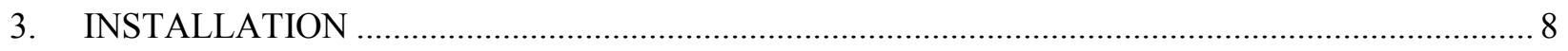

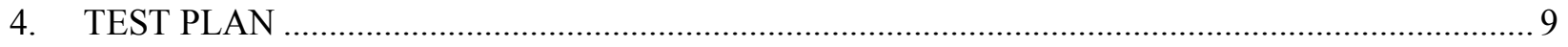

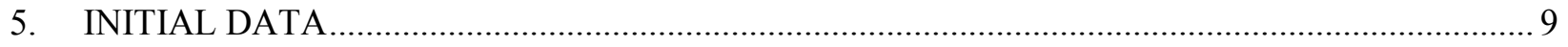

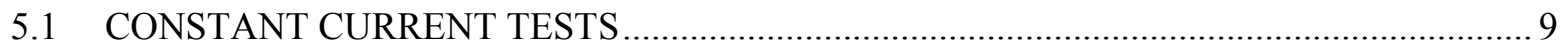

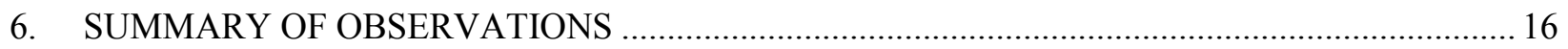

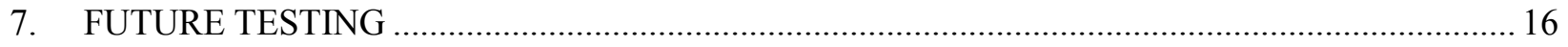

APPENDIX A. CONTROL SYSTEM FOR THE POWERLINE CONDUCTOR ACCELERATED TEST FACILITY .................................................................. A-1

APPENDIX B. THERMOCOUPLE CHANNELS AND LOCATIONS ............................................ B-1 



\section{LIST OF FIGURES}

1. E3X Technology features a high emissivity, low absorptivity surface coating applied to

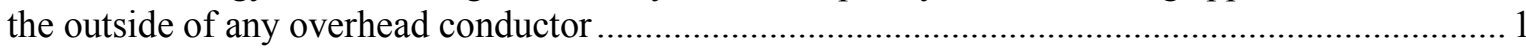

2. Spectrum comparison of solar and conductor thermal radiation ................................................... 2

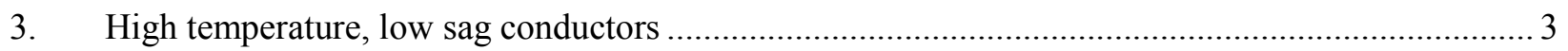

4. Increased operating temperatures of high temperature, low sag conductors .................................. 3

5. Aerial view of the Powerline Conductor Accelerated Test facility ................................................. 4

6. Graphical depiction of the Powerline Conductor Accelerated Test facility

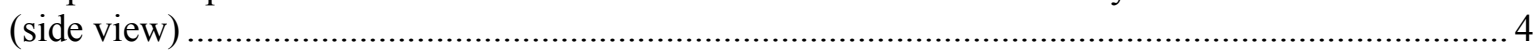

7. Graphical depiction of the Powerline Conductor Accelerated Test facility

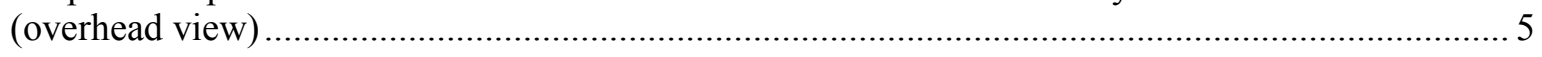

8. Drake/ACSS/MA2/E3X and Drake/ACSS/MA2 _................................................................ 6

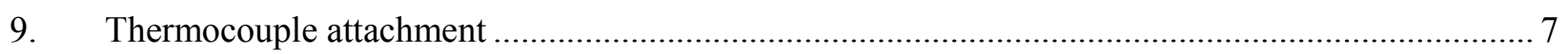

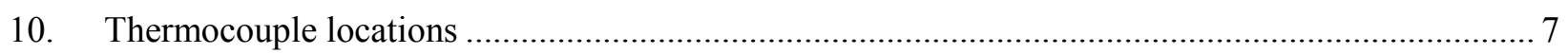

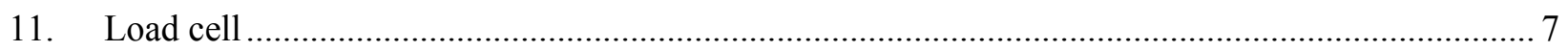

12. Pay-off reel brake failure caused the Drake/ACSS/MA2/E3X conductor to

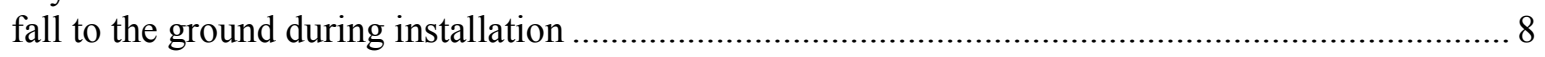

13. Temperature comparison of Drake/ACSS/MA2 and Drake/ACSS/MA2/E3X

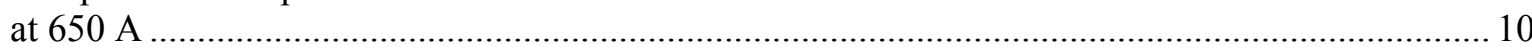

14. Temperature comparison of Drake/ACSS/MA2 and Drake/ACSS/MA2/E3X at $500 \mathrm{~A}$......

15. Temperature comparison of Drake/ACSS/MA2 and Drake/ACSS/MA2/E3X

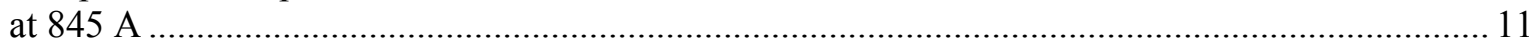

16. Temperature comparison of Drake/ACSS/MA2 and Drake/ACSS/MA2/E3X at $900 \mathrm{~A}$

17. Temperature comparison of Drake/ACSS/MA2 and Drake/ACSS/MA2/E3X

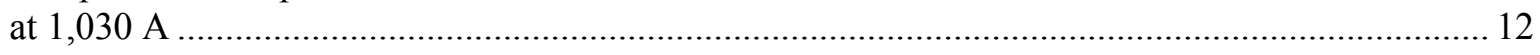

18. Temperature comparison of Drake/ACSS/MA2 and Drake/ACSS/MA2/E3X

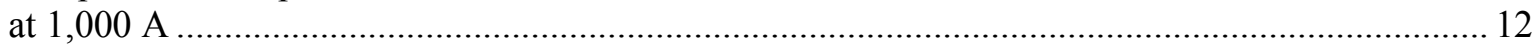

19. Temperature comparison of Drake/ACSS/MA2 and Drake/ACSS/MA2/E3X

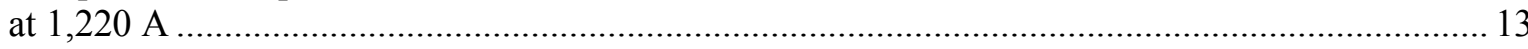

20. Temperature comparison of Drake/ACSS/MA2 and Drake/ACSS/MA2/E3X

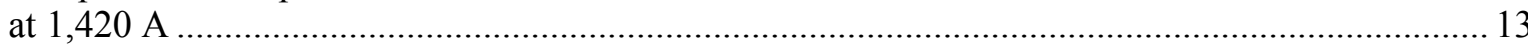

21. Temperature comparison of Drake/ACSS/MA2 and Drake/ACSS/MA2/E3X

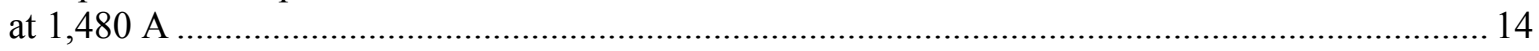

22. Temperature comparison of Drake/ACSS/MA2 and Drake/ACSS/MA2/E3X at $1,420 \mathrm{~A}$ and $1,575 \mathrm{~A}$

23. A reduction in sag (indicating lower temperature) can be seen on the Drake/ACSS/MA2/E3X conductor 


\section{LIST OF TABLES}

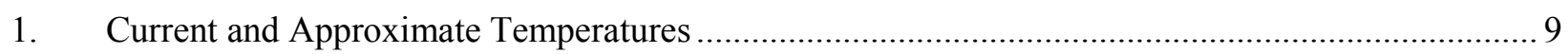

2. Initial Results of Constant Current Testing ............................................................................ 15 


\begin{abstract}
A key to industry acceptance of a new technology is extensive validation in field trials. The Powerline Conductor Accelerated Test facility (PCAT) at Oak Ridge National Laboratory (ORNL) is specifically designed to evaluate the performance and reliability of novel overhead conductor and conductor instrumentation under field conditions. The facility is set up to capture large amounts of data during testing.

General Cable used the ORNL PCAT facility to validate the performance of TransPowr ${ }^{\circledR}$ with E3X ${ }^{\mathrm{TM}}$ Technology - a standard overhead conductor with an inorganic high emissivity, low absorptivity surface coating. Extensive testing has demonstrated a significant improvement in conductor performance across a wide range of operating temperatures with respect to uncoated conductor of the same type, indicating that E3X Technology can provide a reduction in temperature, a reduction in sag, and an increase in ampacity when applied to the surface of any overhead conductor. This report provides initial results of that testing.
\end{abstract}

\title{
1. TECHNOLOGY BACKGROUND
}

Aluminum is the metal of choice for overhead transmission conductors due to its low electrical resistance, weight, and cost. However, aluminum has inherently low emissivity that causes overhead conductors to retain Joule heat generated during transmission of power. When overhead conductors operate at higher temperatures it leads to increased line power loss and conductor sag. The overhead conductor's available thermal rating is limited by aluminum's surface emissivity. Power losses in the United States from generation source to customer meter are estimated to be $6 \%$ or $\$ 20$ billion per year. Transmission and distribution overhead conductor line losses are the dominant source of these power losses.

One way to increase the efficiency of aluminum conductors is to increase their surface emissivity. General Cable's TransPowr with E3X Technology is an overhead conductor with an inorganic high emissivity, low absorptivity surface coating (Fig. 1). The use of this technology allows for achieving significantly lower

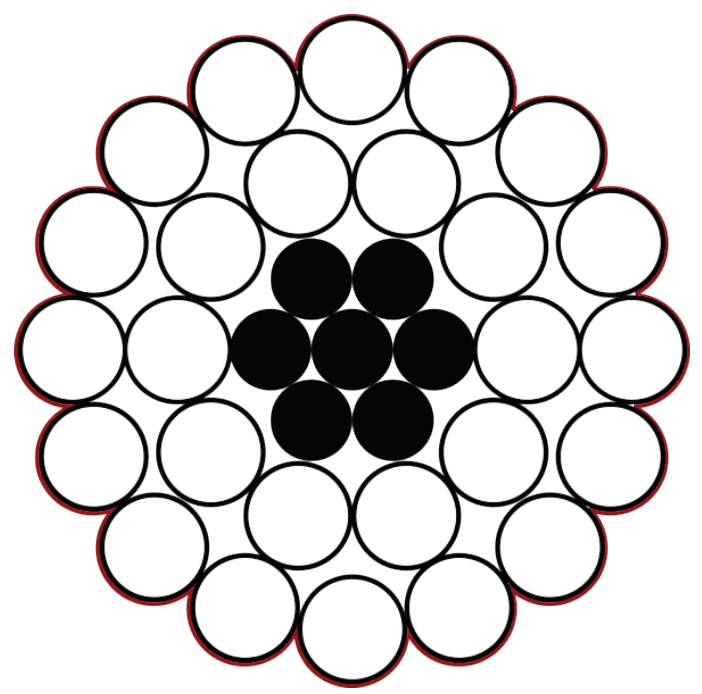

Fig. 1. E3X Technology features a high emissivity, low absorptivity surface coating applied to the outside of any overhead conductor. (Coating not to scale.) operating temperatures for the same current. This surface coating can be applied to all overhead conductors [e.g., all-aluminum (AAC); aluminum, steel-reinforced (ACSR); and aluminum, steelsupported (ACSS)] to provide a performance increase. The resulting conductors maintain the same benefits of the underlying technology but with improved heat dissipation for lower temperature and higher ampacity.

IEEE 738, defines the Standard for Calculating the Current-Temperature Relationship of Bare Overhead Conductors, the radiated heat loss is calculated by the Stefan-Boltzmann law and is dependent on the surface emissivity. 


$$
q_{r}=17.8 * D_{0} * \varepsilon *\left[\left(\frac{T_{s}+273}{100}\right)^{4}+\left(\frac{T_{a}+273}{100}\right)^{4}\right] W / m
$$

Equation 1. Radiated Heat Loss Equation, where $q_{r}$ is radiated heat loss, $D_{0}$ is conductor diameter, $\varepsilon$ is emissivity of the conductor, $T_{s}$ is conductor temperature, and $T_{a}$ is ambient temperature.

The solar heat gain is also provided and is dependent on the surface absorptivity.

$$
q_{s}=\alpha * Q_{s e} * \sin (\theta) * A^{\prime} W / m
$$

Equation 2. Solar Heat Gain Equation, where $q_{s}$ is solar heat gain, $\alpha$ is absorption coefficient, $Q_{s e}$ is total solar and sky radiated heat flux rate, $\theta$ is angle of incidence of sun's rays, and $\boldsymbol{A}$ is conductor area.

Emissivity and absorptivity are equivalent at the same wavelength. However, overhead conductors emit thermal radiation at substantially different wavelengths than the sun does. E3X Technology takes advantage of this scientific phenomena by implementing a spectrally-selective surface coating that radiates heat (has high emissivity) in the far infrared region. This is where conductors radiate, and blocks heat absorption in the visible spectrum where the sun radiates (Fig. 2).

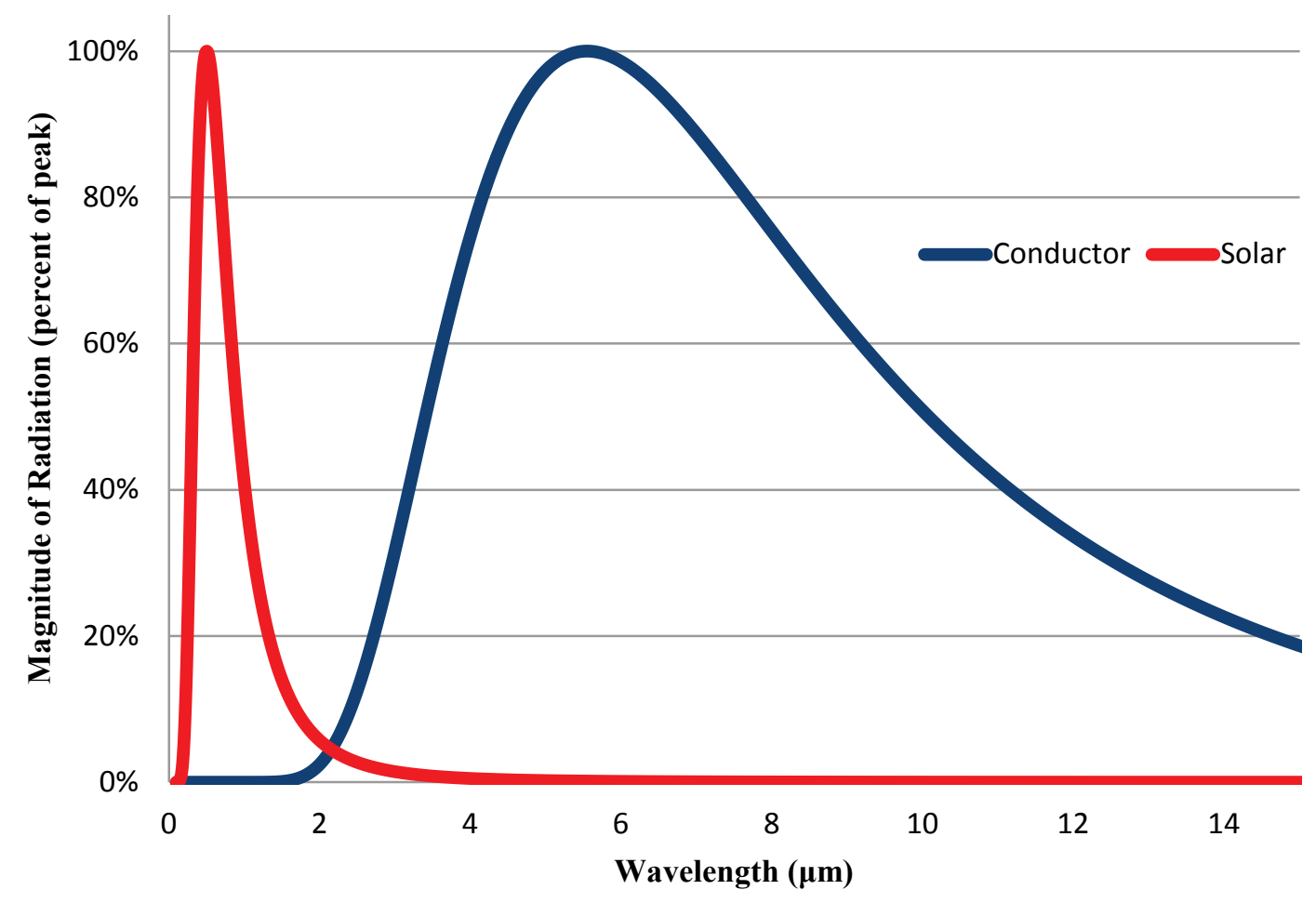

Fig. 2. Spectrum comparison of solar and conductor thermal radiation. (Magnitude expressed as a percentage of peak magnitude.)

Laboratory experiments show a 20\%-30\% reduction in temperature (in degrees Celsius) for the coated conductor when compared to uncoated conductors operating at the same ampacity and environmental conditions. In addition, a coated conductor affords approximately a $20 \%$ increase in ampacity when operating at the same temperature as an uncoated conductor. Because the coating is inorganic and stable in the environment, E3X Technology is expected to provide a benefit for the lifetime of the conductor. 


\section{FACILITY BACKGROUND}

PCAT was developed by ORNL and the US Department of Energy (DOE) in 2003 as a test facility to evaluate the performance of novel overhead conductor designs. The objective of these novel conductors were to carry higher currents with the same or less sag in the conductor (Figs. 3 and 4).

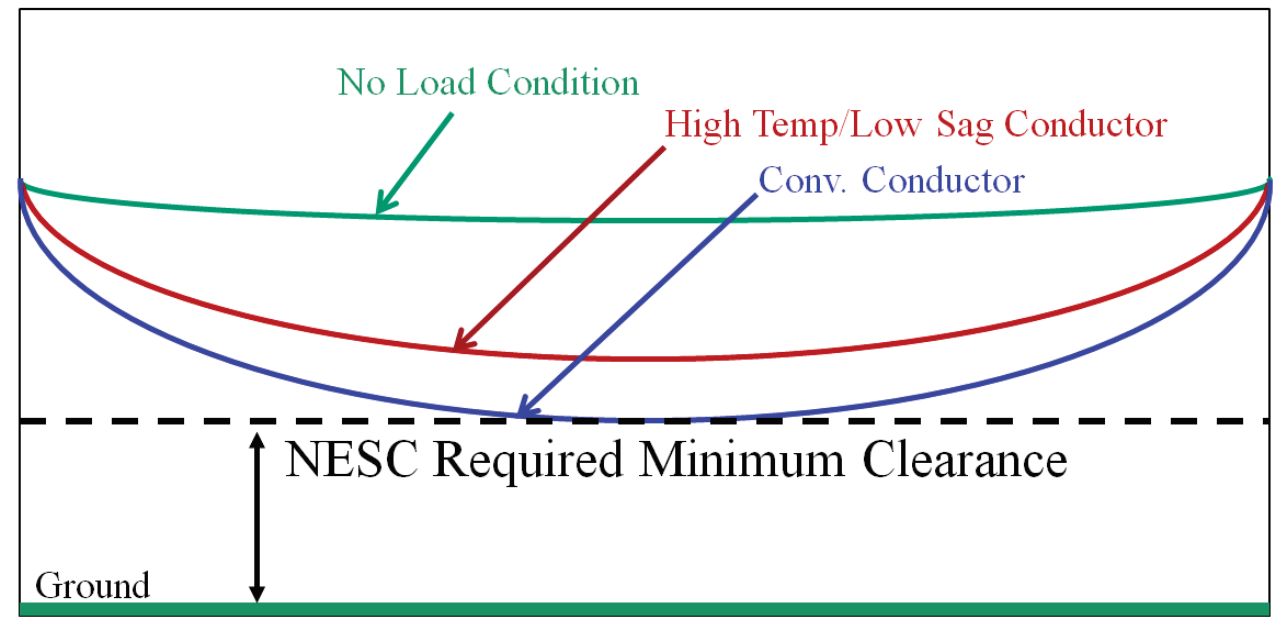

Fig. 3. High temperature, low sag conductors. $($ NESC $=$ National Electrical Safety Code.)

The facility was originally built to meet guidelines in the 2002 DOE National Transmission Grid Study, which stated that "DOE will develop national transmission-technology testing facilities that encourage partnering with industry to demonstrate advanced technologies in controlled environments. Working with TVA, DOE will create an industry cost-shared transmission line testing center at DOE's Oak Ridge National Laboratory (with at least a 50 percent industry cost share).”

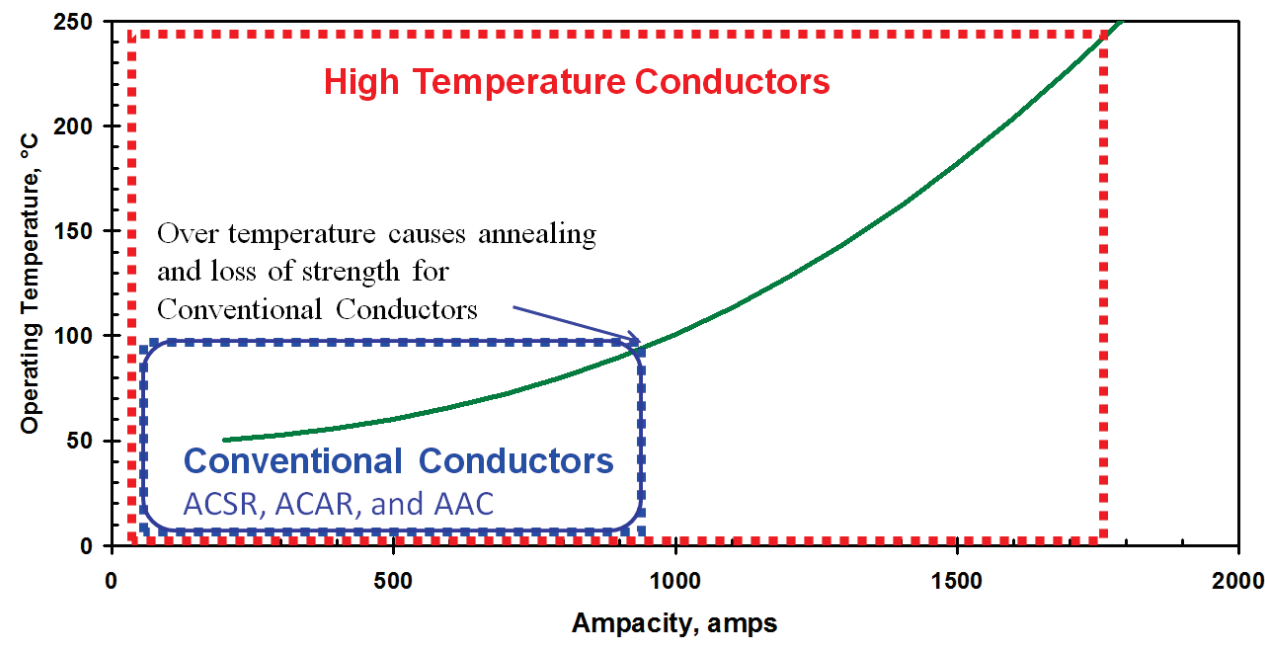

Fig. 4. Increased operating temperatures of high temperature, low sag conductors. (ACSR = aluminum conductor steel-reinforced, ACAR = aluminum cable alloyreinforced, and $\mathrm{AAC}=$ all-aluminum conductor.)

PCAT has been used to successfully field test overhead conductors and conductor instrumentation to demonstrate and validate performance in a real world environment either before or in conjunction with 
field trials. A big hurdle for utility acceptance of novel technologies is field evaluation, and PCAT is able to provide this performance validation through its real-world testing conditions where it is able the accelerate the aging on the conductor and test the lifetime.

PCAT is located at the ORNL campus in Oak Ridge, Tennessee (Fig. 5). PCAT provides is a high-power, heavily instrumented and controlled, platform for performing performance testing of overhead conductors and conductor instrumentation. This includes collecting all the necessary information for overhead conductor characterization and characterization of whole systems, as well as splices and dead ends. The facility is part of a DOE effort to address growing demands for electric power at a time when existing transmission line capacity is nearing its limits. PCAT is also used to test advanced sensors and controls for overhead conductors.

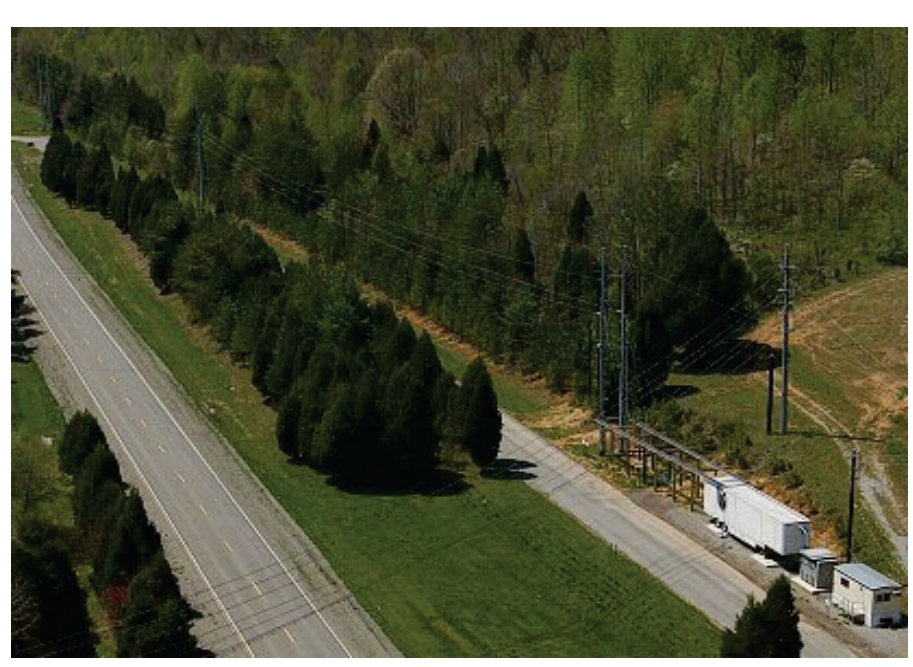

Fig. 5. Aerial view of the Powerline Conductor Accelerated Test facility.

PCAT accommodates 2,400 ft of

overhead test conductor in a loop arrangement across two $600 \mathrm{ft}$ segments. The facility consists of five $161 \mathrm{kV}$-rated steel transmission poles that have extensive support to ensure mechanical stability, with two poles at each of the two dead ends and one in mid-span. The test line forms the load for the power supply by creating a loop and connecting its two ends to the two terminals of the power source. The power source is a controllable dc power supply that provides dc current up to 5,000 A (Figs. 6 and 7).

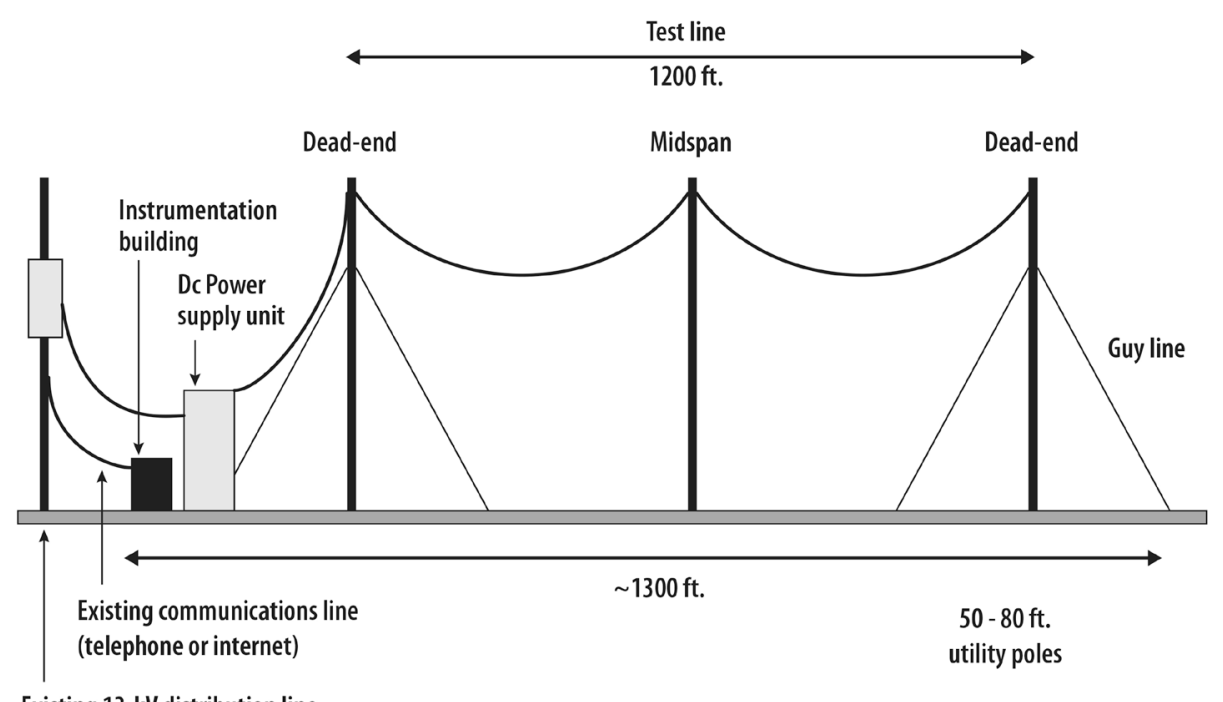

Existing 13-kV distribution line

Fig. 6. Graphical depiction of the Powerline Conductor Accelerated Test facility (side view). 
Total length $\sim 1300 \mathrm{ft}$.

DC

Trans- Power

former

Power Test conductors

utility poles

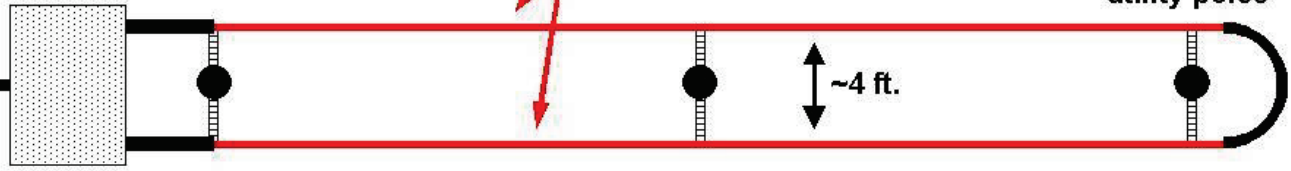

Test Line $=1200 \mathrm{ft} .(2-600 \mathrm{ft}$. spans $)$

Instrumentation shed

Existing communications line

(telephone or internet)

Existing 13.8-kV distribution line

Fig. 7. Graphical depiction of the Powerline Conductor Accelerated Test facility (overhead view).

Because all tests at PCAT are at relatively low voltage (typically less than $100 \mathrm{Vdc}$ ), it is possible to place extensive instrumentation in direct contact with the test conductors. Measurement capability at PCAT include surface and core temperatures of the conductor under test and simultaneous measurement of conductor voltage, current, tension, sag, and environmental conditions (e.g., wind, solar, ambient). A messenger line with fiber optic loops and a $120 \mathrm{~V}$ instrumentation line are available above the test line to provide control power and communication for instrumentation. (See Appendix A for more information on the PCAT control system and Appendix B for more information placement of thermocouples at PCAT for conductor surface and core measurements.)

\subsection{TEST HARDWARE}

The following overhead conductor hardware was used in the TransPowr with E3X Technology testing.

- 795 kcmil Drake/ACSS/MA2/E3X (Fig. 8)

- 795 kcmil Drake/ACSS/MA2 (Fig 8)

- $\quad$ Four dead-end clamps: AFL HiTemp compression dead ends (AFL 33100 HT); AFL filled with AFL HiTemp filler compound (ACFCHT10T

- Two suspension clamps: Preformed Line Products Thermolign suspension clamps (AGS-5130HT) 

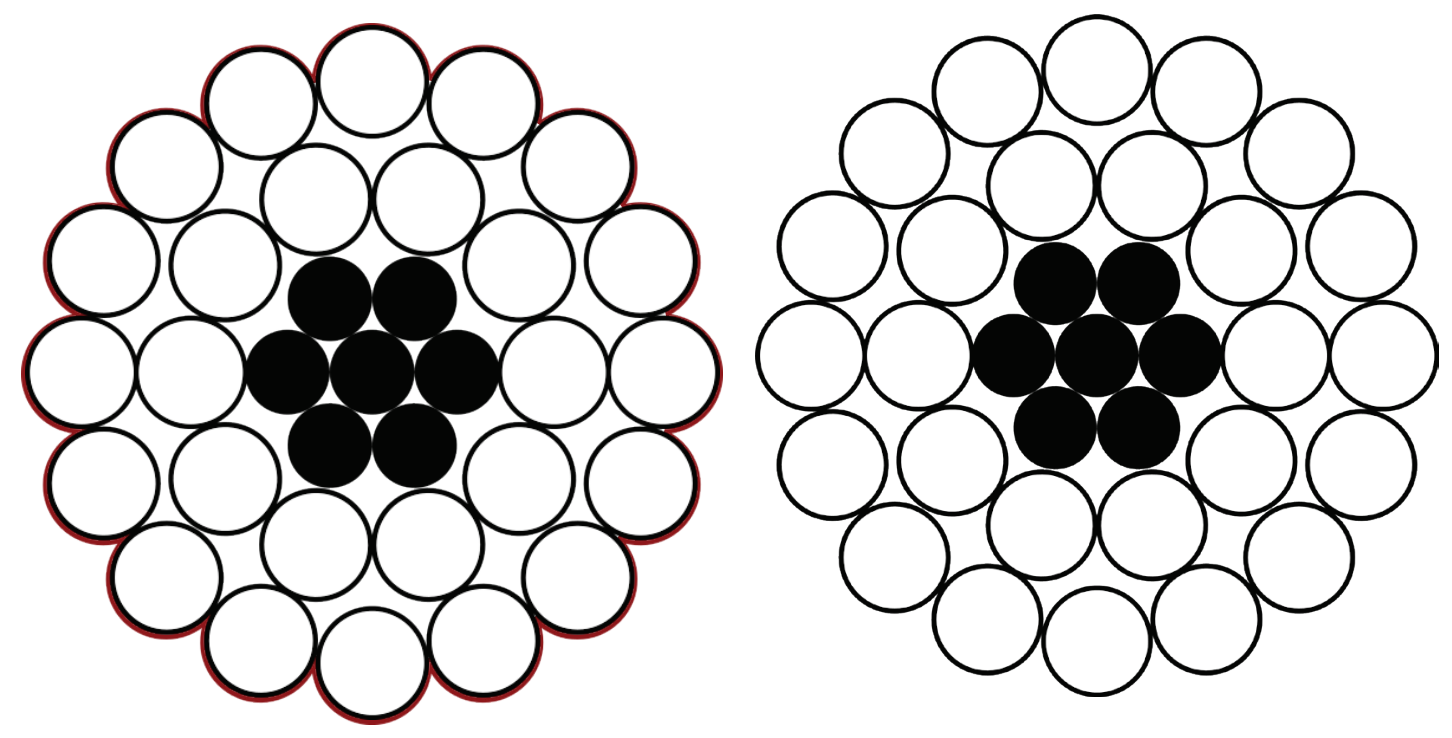

Fig. 8. Drake/ACSS/MA2/E3X (left) and Drake/ACSS/MA2 (right).

dc power source. A $2.25 \mathrm{MW}$ controllable dc power source provides current to the test conductor. The power source is fed by a $13.8 \mathrm{kV} / 4,160 \mathrm{~V}$ transformer. The power supply is rated to change the current from 0 to 5,000 Adc and voltage from 0 to $400 \mathrm{Vdc}$. A manual limit can be set to prevent the power supply from operating above a specified current. A conductor temperature limit, based on the real-time measured conductor temperature, can be set to prevent damage to the conductor and accessories.

Instrumentation. During testing, the following instrumentation elements and measurements provide feedback information for the control system.

- $\quad$ Type T thermocouples placed directly on the conductor surface (Figs. 9 and 10).

- Conductor tension measurements taken by two load cells located on the transmission poles adjacent to the dc power source. The load cell is a transducer that converts the measured force into an electrical signal (Fig. 11).

- Conductor clearance, or sag, determined with a laser range finder located at the midpoint of the first conductor span just above ground level. A reflective plate (laser target) is attached to the conductor directly above the laser to measure vertical displacement.

- The current passed through the conductor and the voltage drop determined by the measured output of the dc power supply.

- A weather station located on the top of the first pole provides ambient temperature, wind speed, wind direction, and solar radiation.

- A net radiation sensor measures the conductor temperature due to ambient conditions. 


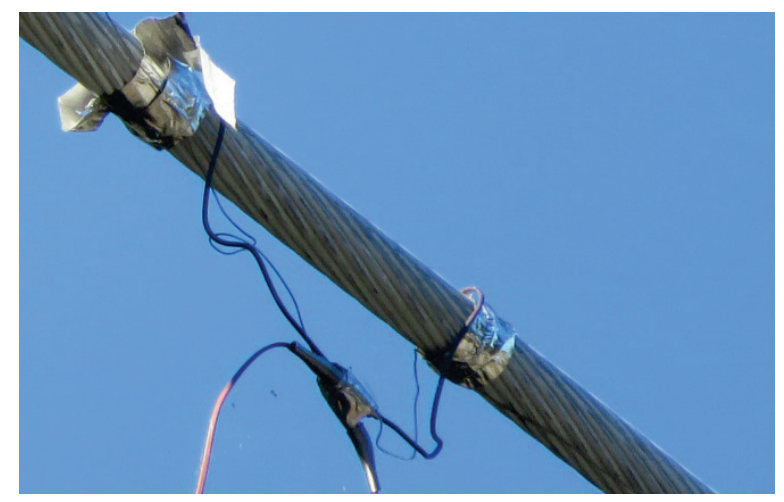

Fig. 9. Thermocouple attachment.

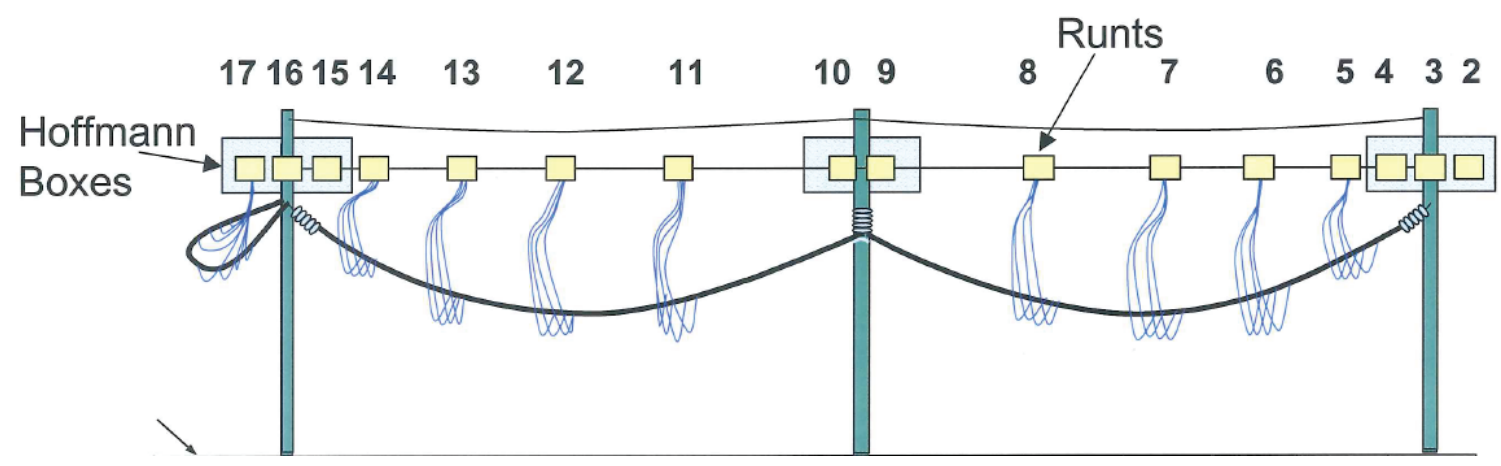

Fig. 10. Thermocouple locations (eight COYOTE runts and three pole-mount enclosures connected by two fiber networks).

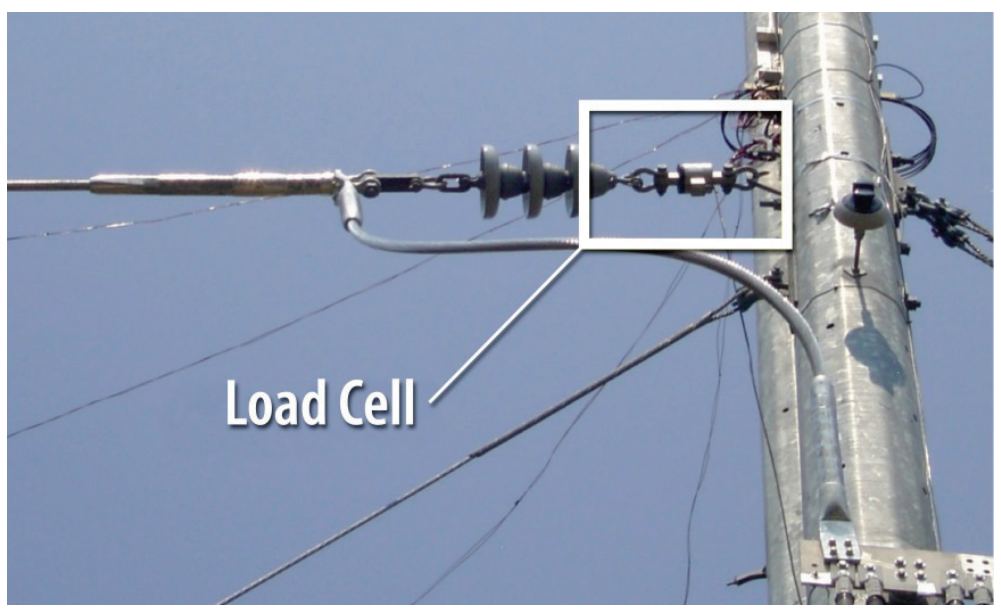

Fig. 11. Load cell. 
Data acquisition and control system. A LabVIEW-based data acquisition and control system is used to capture PCAT data and provide the appropriate control to maintain test set points. Currently this system is being upgrade to include more functionality including visualization, historical trends, etc.

\section{INSTALLATION}

Installation services were provided by the Tennessee Valley Authority. General Cable provided one reel containing 3,000 ft of Drake/ACSS/MA2 and one reel containing 3,000 ft of Drake/ACSS/MA2/E3X produced at General Cable's manufacturing facility for this installation. The reels were inspected before installation, and no damage was found to either the surface coating or the conductor.

The conductors were installed by the semi-tension method, pulling straight from the pay-off reel and using the brake to maintain clearance from the ground.

Drake/ACSS/MA2/E3X was installed on the tree side of the poles while standard Drake/ACSS/MA2 was installed on the road side. Figure 12 shows context of treeside and roadside. Roadside is the closest to Old Bethel Valley Rd which is shown.

It was noted during installation that several trees extended into the right-ofway, and the E3X conductor was being pulled through the trees. In addition, the pay-off reel brake proved inadequate to maintain clearance, causing the conductor to intermittently strike the ground in front of the reel. About three-quarters of the way through the pull the pay-off reel brake gave way, resulting in the E3X conductor falling to the ground (Fig. 12). The pull was stopped and the conductor was assessed for damage. The conductor was deemed unharmed and the brake was fixed. The pull continued and was completed without additional problems.

The Drake/ACSS/MA2 conductor was

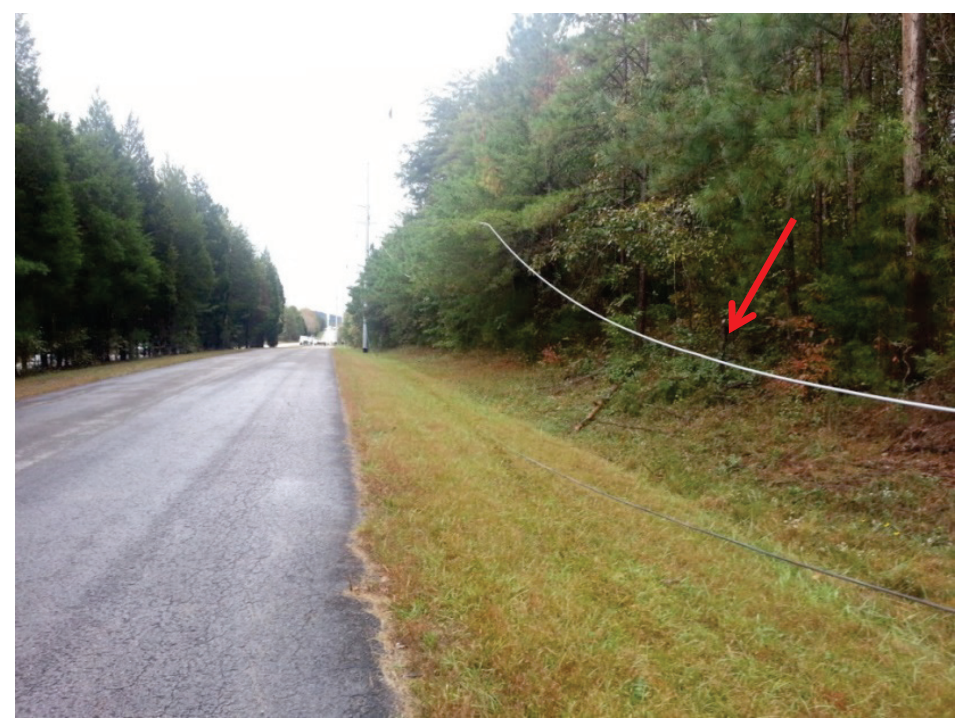

Fig. 12. Payoff reel brake failure caused the Drake/ACSS/ MA2/E3X conductor to fall to the ground during installation. installed the next day with another reel trailer, and no problems were encountered during the installation.

The individual conductors were sagged and clipped in at the same tension to ensure identical installation conditions. The conductors were electrically terminated with compression dead ends using standard installation practices. They were then jumper at the last tower to join the circuit. The outer surfaces of the conductor ends were prepared by wire brushing to remove the coating and aluminum oxide before insertion in the compression dead ends. Wire brushing was not necessary for the suspension clamps.

Once installation was finished, the trees growing into the test line right-of-way were cut back before testing was initiated. 


\section{TEST PLAN}

The conductors are being tested according to the following test plan.

1. Constant current tests. Current tests will be performed at the temperatures shown in Table 1. For each test, the current will be held constant for about 24 hours. The currents shown in Table 1 are approximate; the actual currents to be used will be calculated based on local weather conditions at the time of the tests and IEEE 738, assuming nighttime weather conditions (no sun) with no wind.

Table 1. Current and Approximate Temperatures

\begin{tabular}{cc}
\hline $\begin{array}{c}\text { Target Temperature Drake/ACSS/MA2 } \\
\left({ }^{\circ} \mathbf{C}\right)\end{array}$ & $\begin{array}{c}\text { Approximate Current } \\
(\mathbf{A})^{\boldsymbol{a}}\end{array}$ \\
\hline 30 & 650 \\
50 & 500 \\
60 & 845 \\
90 & 900 \\
100 & 1,030 \\
110 & 1,000 \\
150 & 1,220 \\
200 & 1,420 \\
225 & 1,480 \\
250 & 1,575 \\
\hline
\end{tabular}

${ }^{a}$ Adjusted for local weather conditions on day of test.

2. Current thermal/mechanical cycling tests. The conductor will be thermally and mechanically cycled 500 times. The duration of each cycle will be 3 hours. For each cycle, with the conductor at ambient temperature, a dc current will be applied for 1.5 hours to heat the conductor. During this time period, a constant current will be applied for 30 to 45 minutes to quickly heat the conductor to its rated operating temperature, and then the current will be modulated for the remainder of the 1.5 hours to maintain the set operating temperature. At the end of the 1.5 hours, the current will be shut off and the conductor allowed to cool back to near ambient temperature for 1.5 hours. Eight thermal cycles can be completed in a single day, and 500 thermal cycles can be completed in approximately 64 days of testing.

3. Repeat constant current tests. Current tests will be repeated at the current and temperatures shown in Table 1. For each test, the current will be held constant for about 24 hours.

\section{INITIAL DATA}

\subsection{CONSTANT CURRENT TESTS}

Constant current was applied to the line and the temperature was monitored on both conductors.

Figures 13-22 show the temperature values from the thermocouples installed midpoint on the spans. The data were plotted using a 30 -point moving average. Each chart represents a single ( 24 hour period) of testing at constant current. Each day a different maximum conductor temperature was targeted. Table 2 
shows initial results of the constant current tests, and Fig. 23 shows the reduction in sag for the Drake/ACSS/MA/E3X conductor.

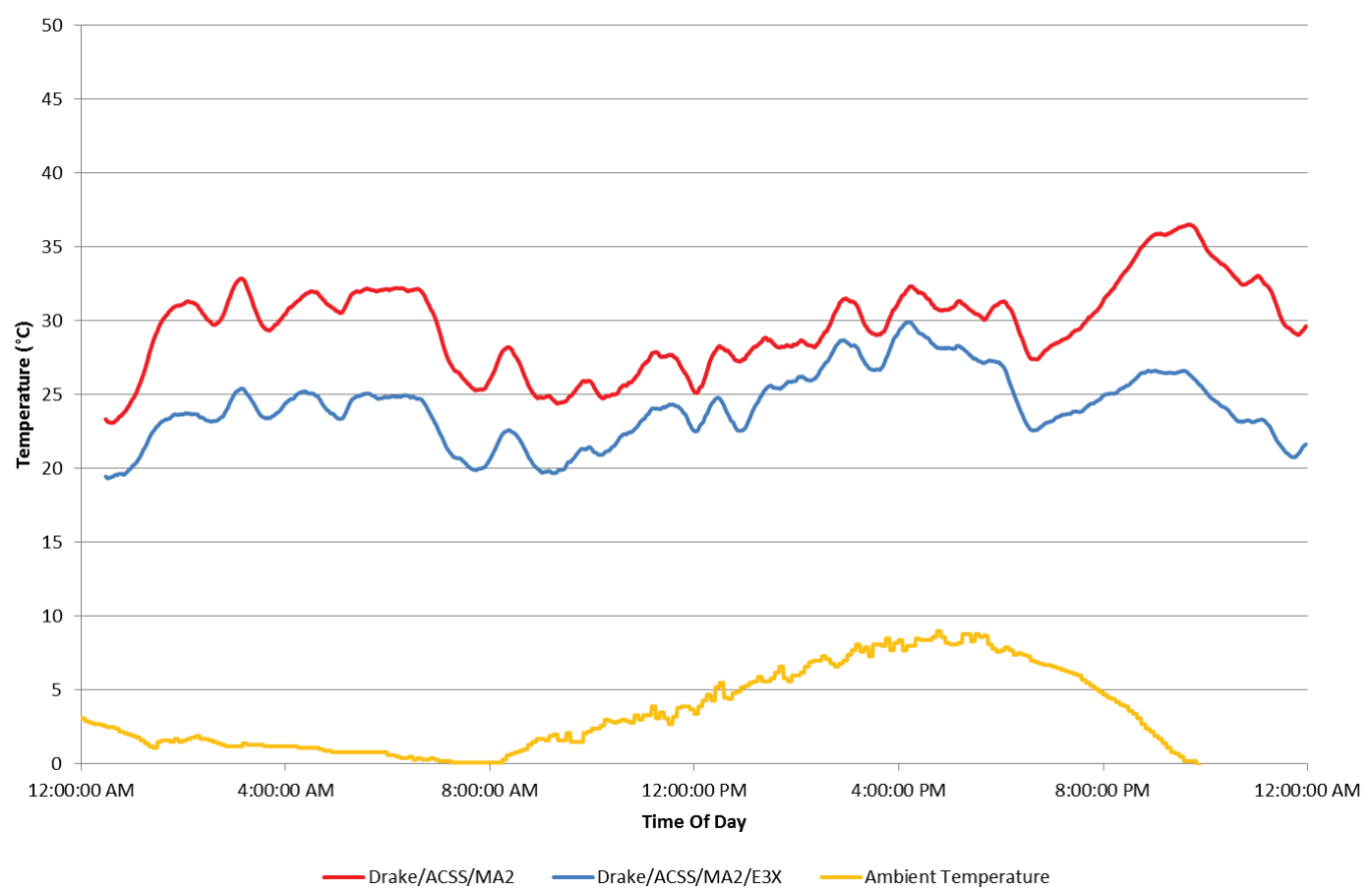

Fig. 13. Temperature comparison of Drake/ACSS/MA2 and Drake/ACSS/MA2/E3X at 650 A (channel 7, midspan).

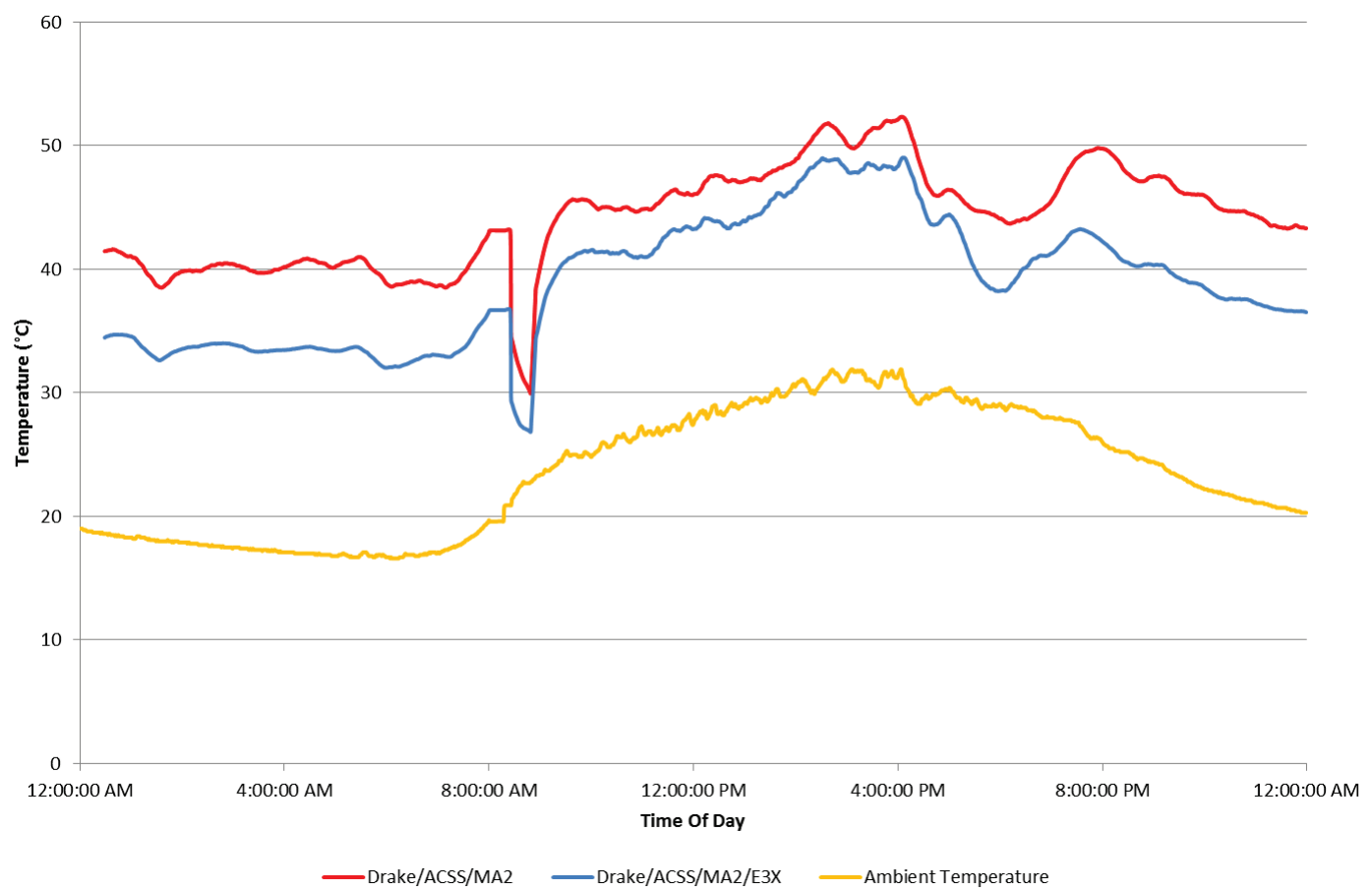

Fig. 14. Temperature comparison of Drake/ACSS/MA2 and Drake/ACSS/MA2/E3X at 500 A (channel 7, midspan). 


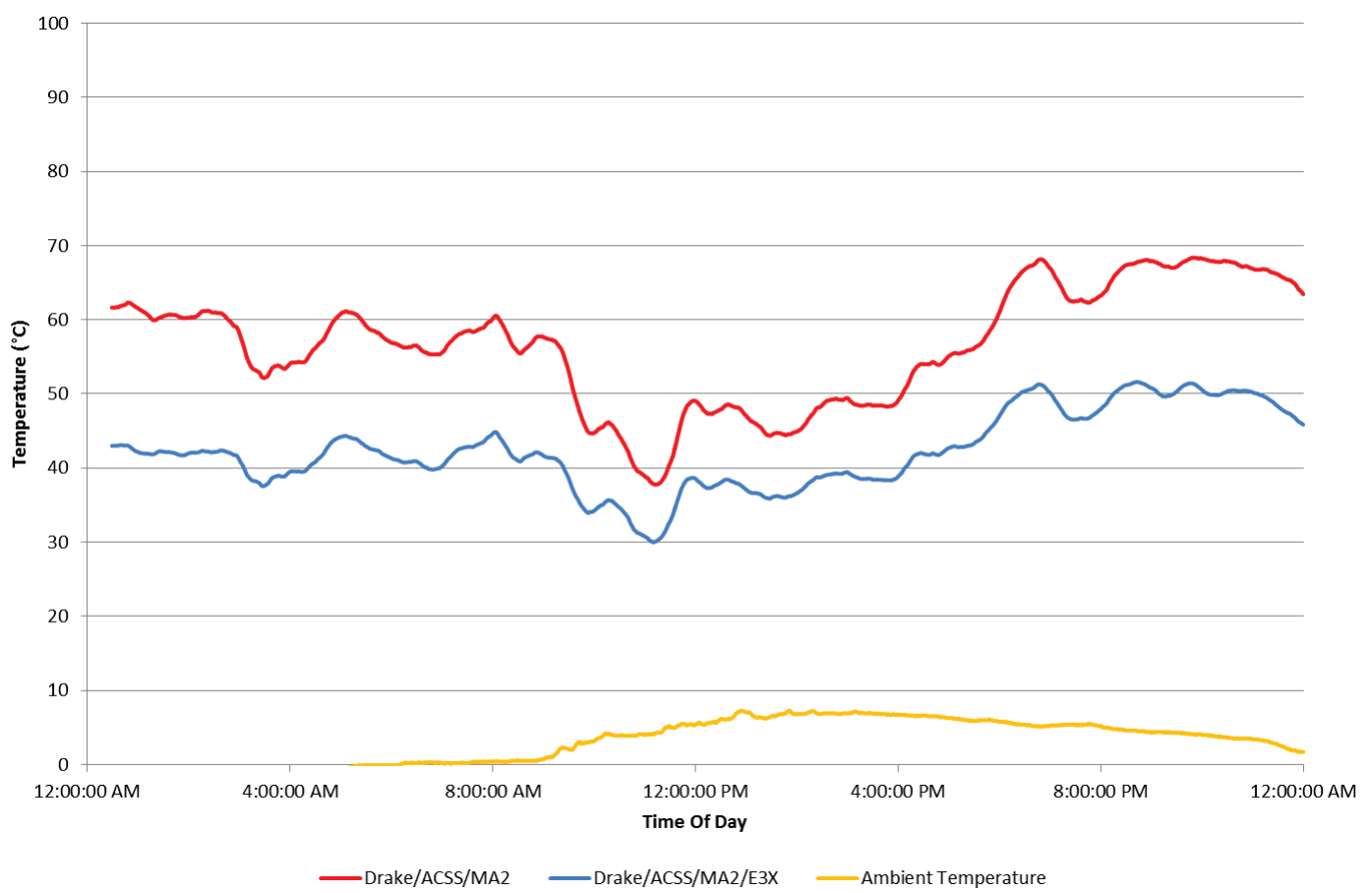

Fig. 15. Temperature comparison of Drake/ACSS/MA2 and Drake/ACSS/MA2/E3X at 845 A (channel 13, midspan).

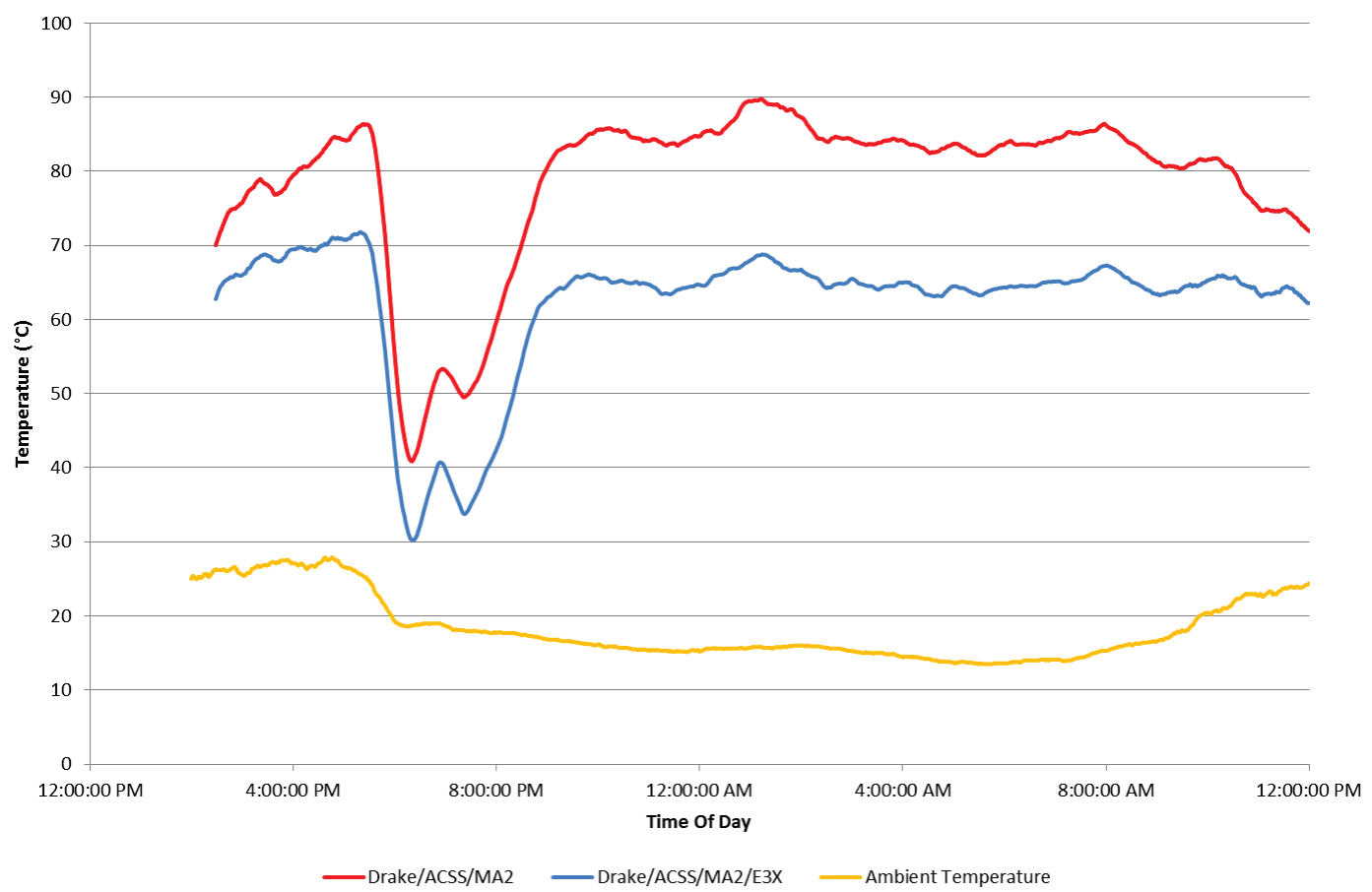

Fig. 16. Temperature comparison of Drake/ACSS/MA2 and Drake/ACSS/MA2/E3X at 900 A (channel 7, midspan). 


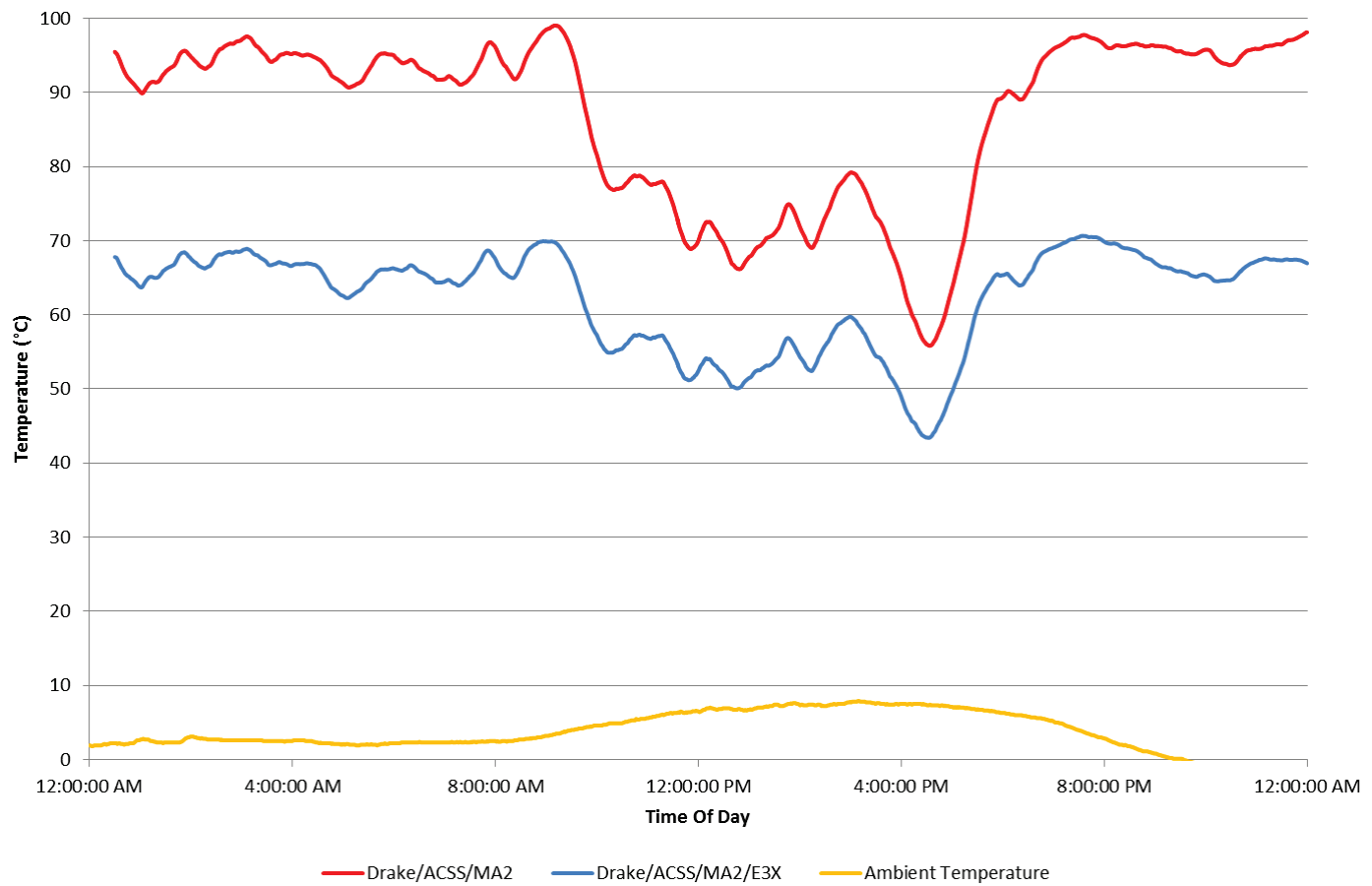

Fig. 17. Temperature comparison of Drake/ACSS/MA2 and Drake/ACSS/MA2/E3X at 1,030 A (channel 13, midspan).

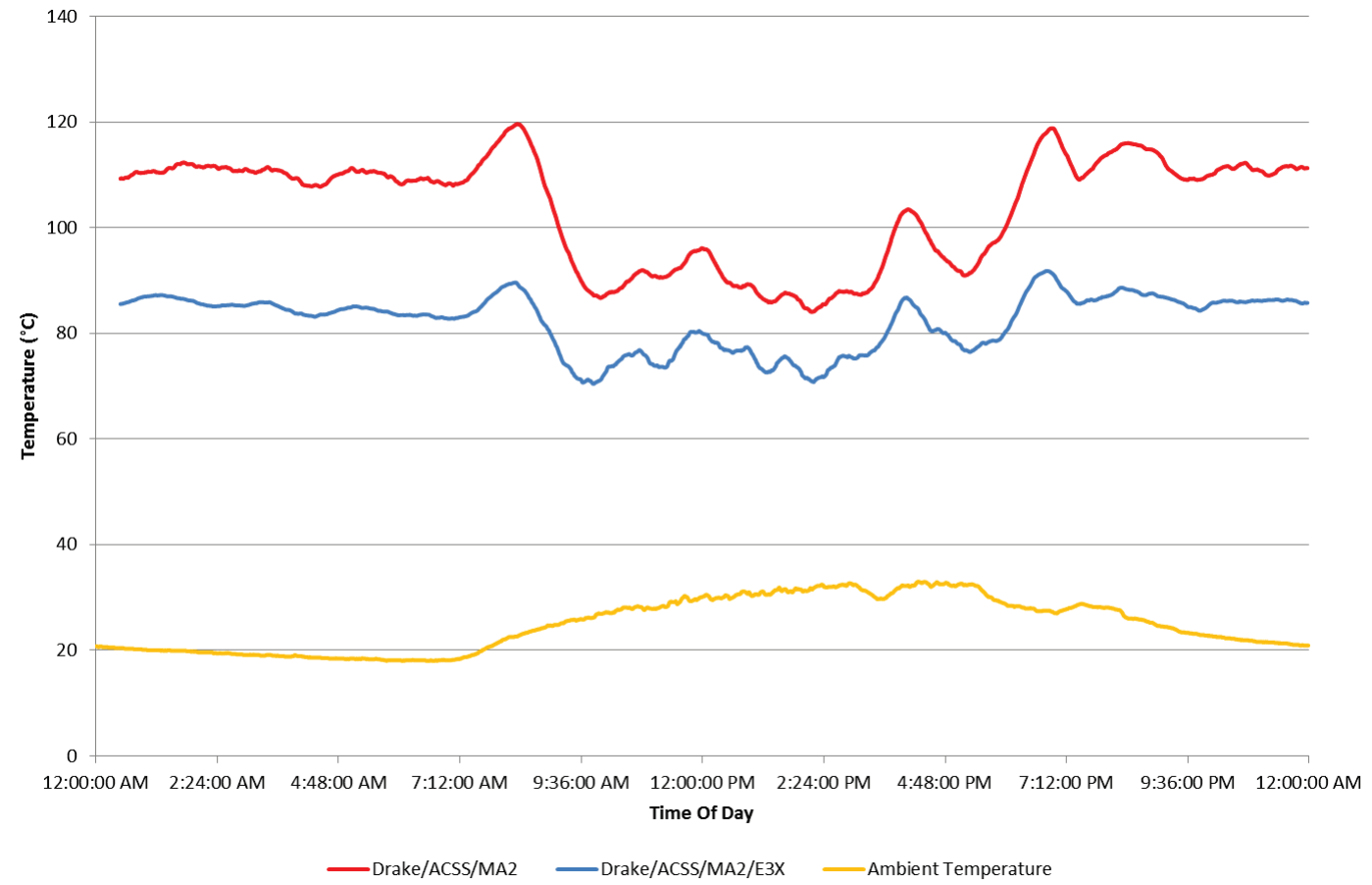

Fig. 18. Temperature comparison of Drake/ACSS/MA2 and Drake/ACSS/MA2/E3X at 1,000 A (channel 7, midspan). 


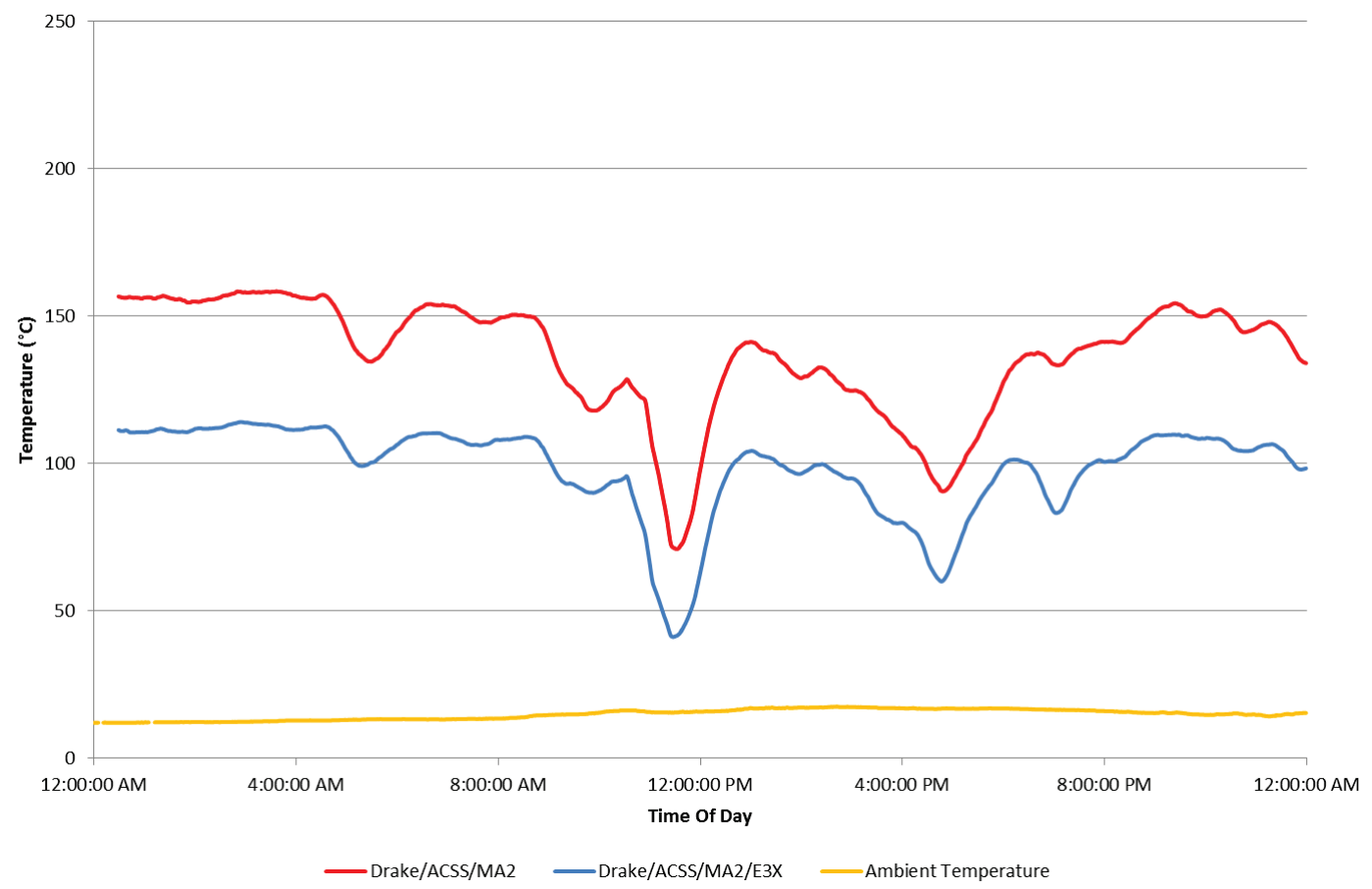

Fig. 19. Temperature comparison of Drake/ACSS/MA2 and Drake/ACSS/MA2/E3X at 1,220 A (channel 7, midspan).

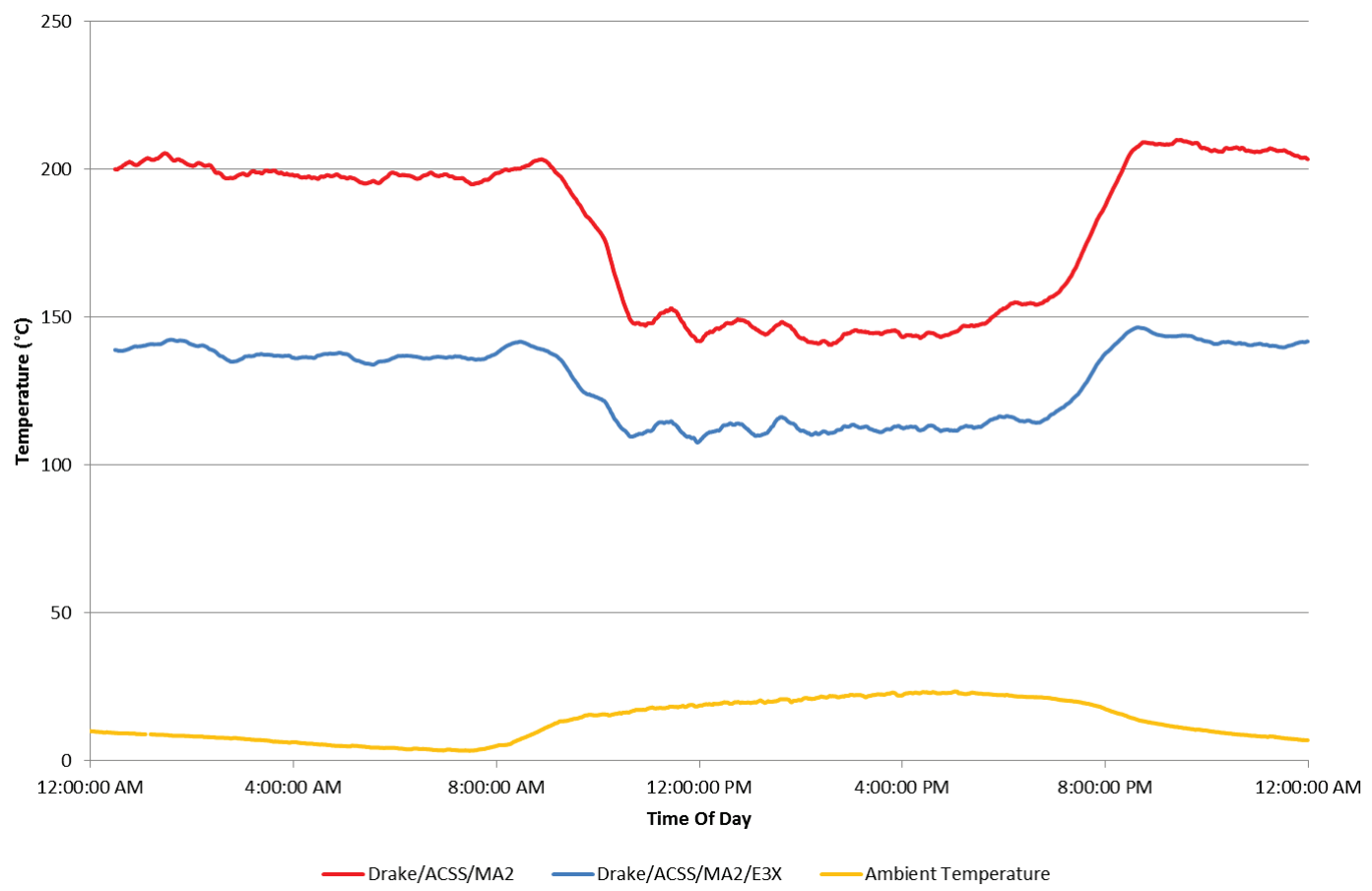

Fig. 20. Temperature comparison of Drake/ACSS/MA2 and Drake/ACSS/MA2/E3X at 1,420 A (channel 7, midspan). 


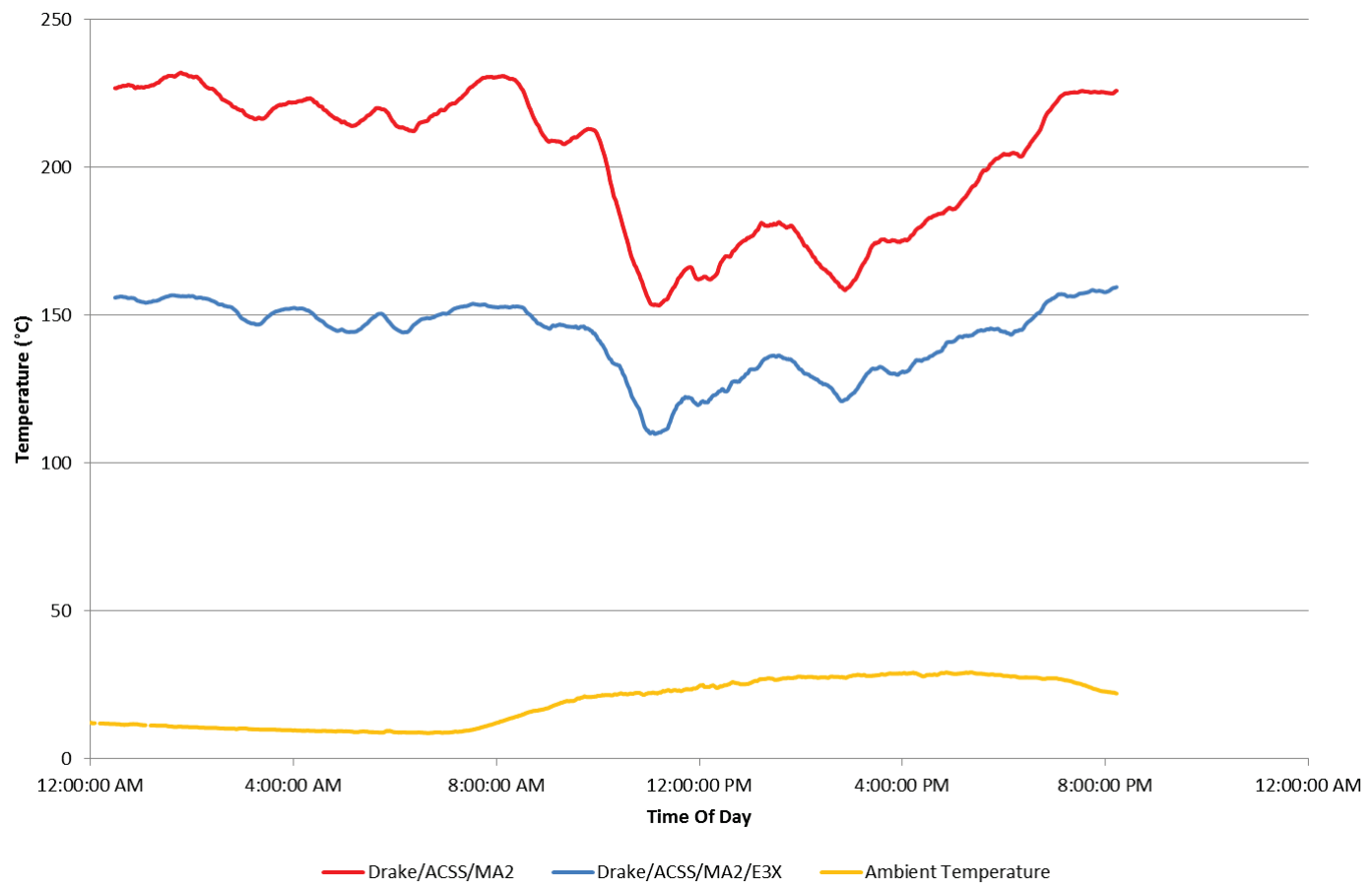

Fig. 21. Temperature comparison of Drake/ACSS/MA2 and Drake/ACSS/MA2/E3X at 1,480 A (channel 7, midspan).

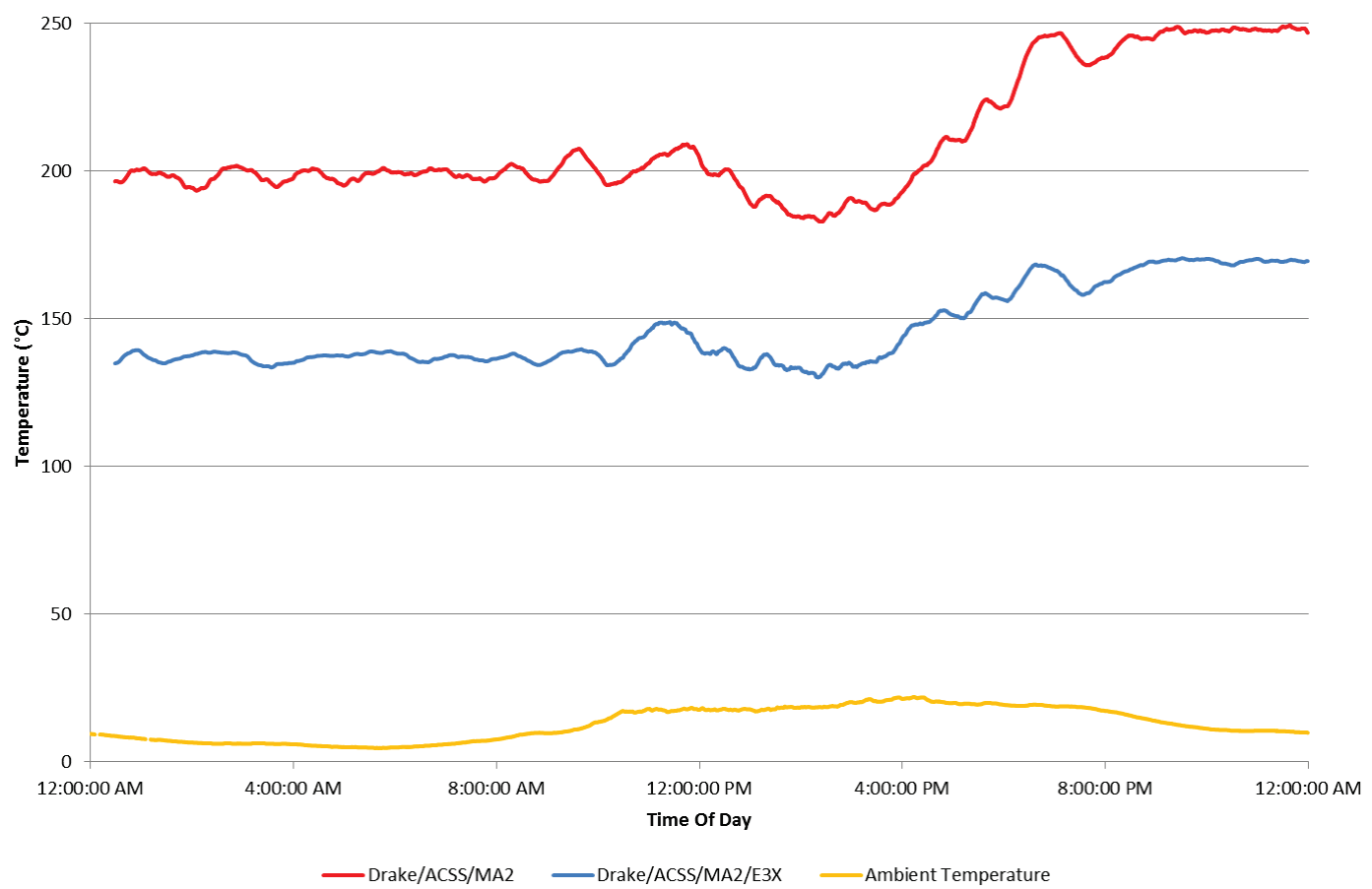

Fig. 22. Temperature comparison of Drake/ACSS/MA2 and Drake/ACSS/MA2/E3X at 1,420 A and 1,575 A (channel 7, midspan). 
Table 2. Initial Results of Constant Current Testing

\begin{tabular}{cccccc}
\hline $\begin{array}{c}\text { Ambient } \\
\text { Temperature } \\
\left({ }^{\circ} \mathbf{C}\right)\end{array}$ & $\begin{array}{c}\text { Wind Velocity } \\
(\mathbf{f t} / \mathbf{s})\end{array}$ & \multicolumn{2}{c}{$\begin{array}{c}\text { Temperature } \\
\left({ }^{\circ} \mathbf{C}\right)\end{array}$} & $\begin{array}{c}\text { Temperature } \\
\text { Reduction } \\
(\%)\end{array}$ & $\begin{array}{c}\text { Differential } \\
\text { Sag } \\
(\mathbf{f t})\end{array}$ \\
\cline { 3 - 5 } & & Drake/ACSS/MA2 & Drake/ACSS/MA2/E3X & \\
\hline 9 & $1.1-3.6$ & 90 & 72 & 20 & 0.5 \\
8 & $0-4.7$ & 119 & 90 & 24 & 0.7 \\
8 & $4.4-5.7$ & 125 & 94 & 25 & 0.9 \\
6 & $0.2-3.2$ & 166 & 125 & 25 & 1.5 \\
6 & $0.4-4.8$ & 200 & 150 & 25 & 1.6 \\
4 & N/A & 240 & 174 & 28 & 2.25 \\
2 & $2.1-2.2$ & 275 & 190 & 31 & 2.85 \\
\hline
\end{tabular}

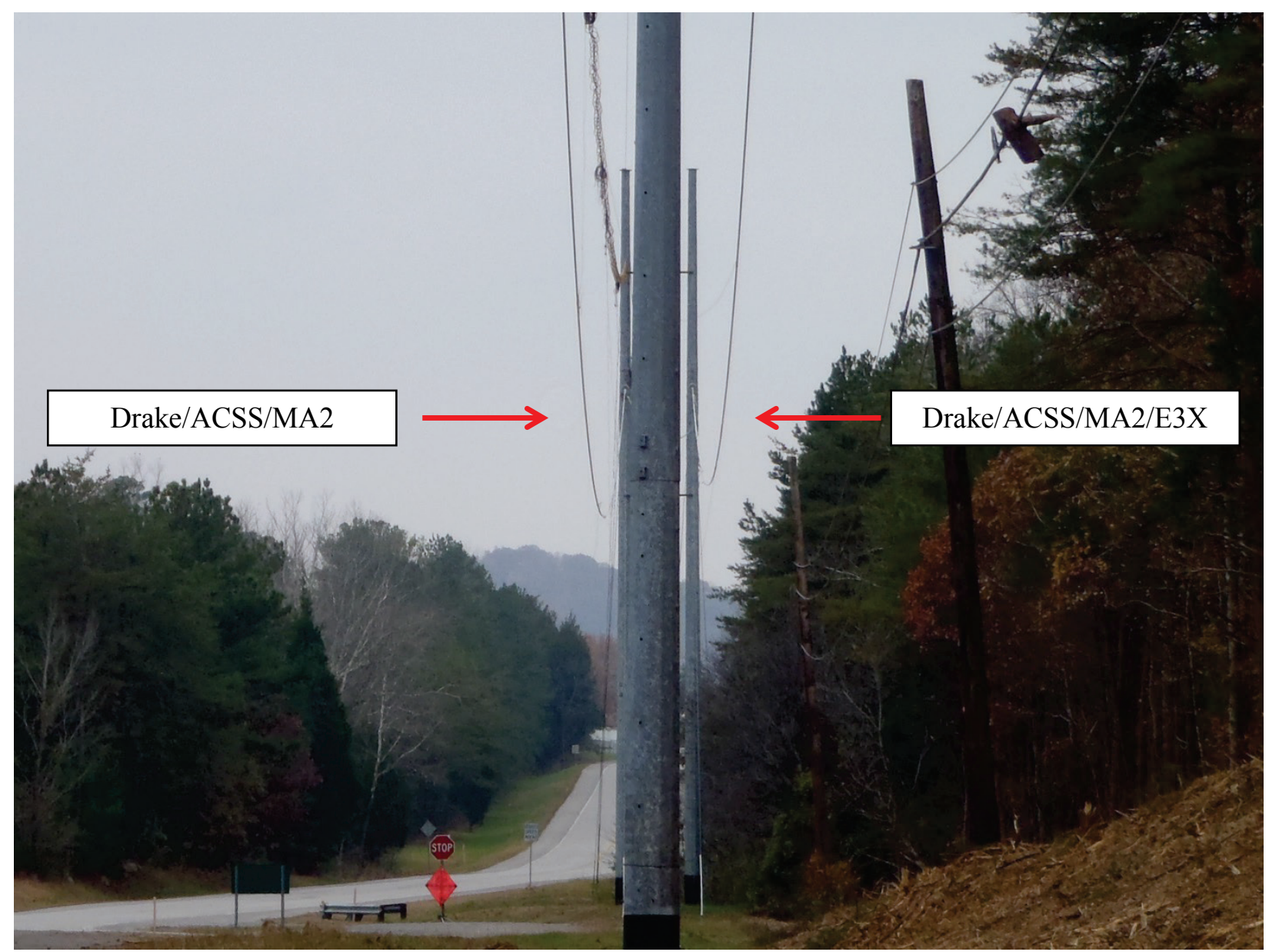

Fig. 23. A reduction in sag (indicating lower temperature) can be seen on the Drake/ACSS/MA2/E3X conductor. 


\section{SUMMARY OF OBSERVATIONS}

Drake/ACSS/MA2/E3X conductor was evaluated side by side with Drake/ACSS/MA2 (standard) conductor at PCAT under a wide range of currents over a period of time from the fourth quarter of 2014 to the third quarter of 2015. Drake/ACSS/MA2/E3X conductor showed on average a $20 \%-31 \%$ reduction in conductor temperature when compared to Drake/ACSS/MA2 conductor operating at conductor temperatures ranging from $90^{\circ} \mathrm{C}$ to $275^{\circ} \mathrm{C}$. The reduction in conductor temperature for Drake/ACSS/MA2/E3X conductor increased as the current increased. Consistent with the temperature measurements, sag measurements showed that Drake/ACSS/MA2/E3X conductor has significantly less sag than Drake/ACSS/MA2 conductor at the same operating conditions.

\section{FUTURE TESTING}

The Drake/ACSS/MA2/E3X and Drake/ACSS/MA2 conductors will remain in the air for an extended period of time for ongoing field analysis to thoroughly evaluate the durability and environmental stability of the technology. The conductors will undergo 500 current cycles consisting of 1.5 hours on and 1.5 hours off. Once the current thermal/mechanical cycling testing is completed, the initial constant current test will be repeated. 


\section{APPENDIX A. CONTROL SYSTEM FOR THE POWERLINE CONDUCTOR ACCELERATED TEST FACILITY}

The Oak Ridge National Laboratory Powerline Conductor Accelerated Test facility has had a long history of testing conductors and acquiring detailed measurements for conductors in the field. The current system, which has been in place for more than 10 years, is described here, along with revitalization efforts to modernize the system. Originally the system was controlled by a set of codes in Visual Basic that ran during the test on a desktop computer. Over time, issues have arisen related to requests for more rapid data acquisition and improved system control. Updating parameters and controls has been complicated in the past by the need for detailed knowledge of the original coding and the need to take the system offline to update the parameters. Figure A.1 shows the current data acquisition system, which can accommodate up to 128 thermocouple measurements, current and voltage measurements, conductor sag, conductor tension, and weather conditions.

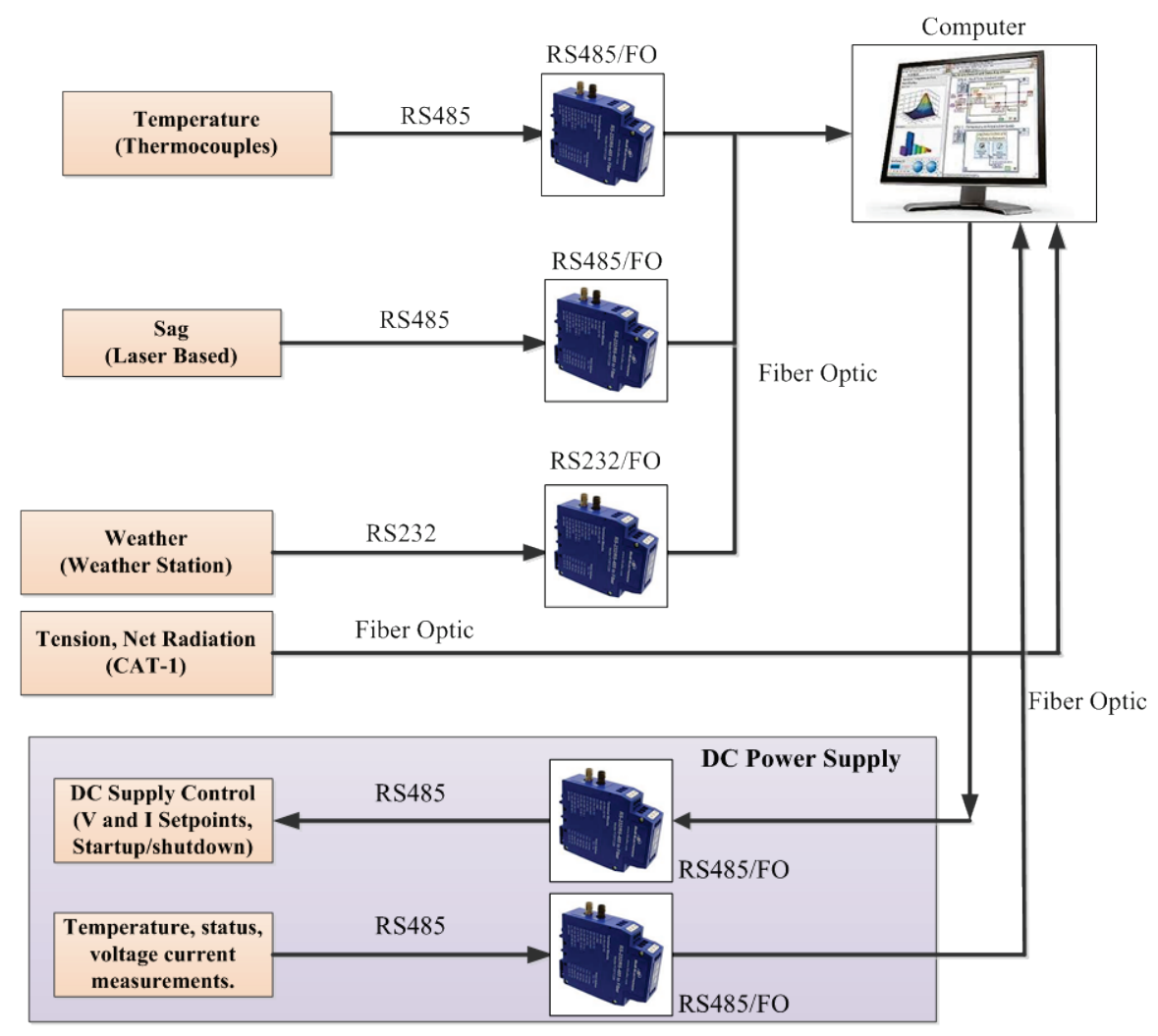

Fig. A.1. Current operating system for the Powerline Conductor Accelerated Test facility.

As part of test system upgrade efforts, a new data acquisition system is being deployed. The biggest change is transitioning the system software from Visual Basic to LabVIEW. To design the system in the most versatile way possible, a design known as "actor framework" has been chosen for the LabVIEW software integration. This type of system will permit asynchronous, parallel measurement, processing, and control. It also allows seamless integration of additional measurements. Figure A.2 shows the proposed new system design. 


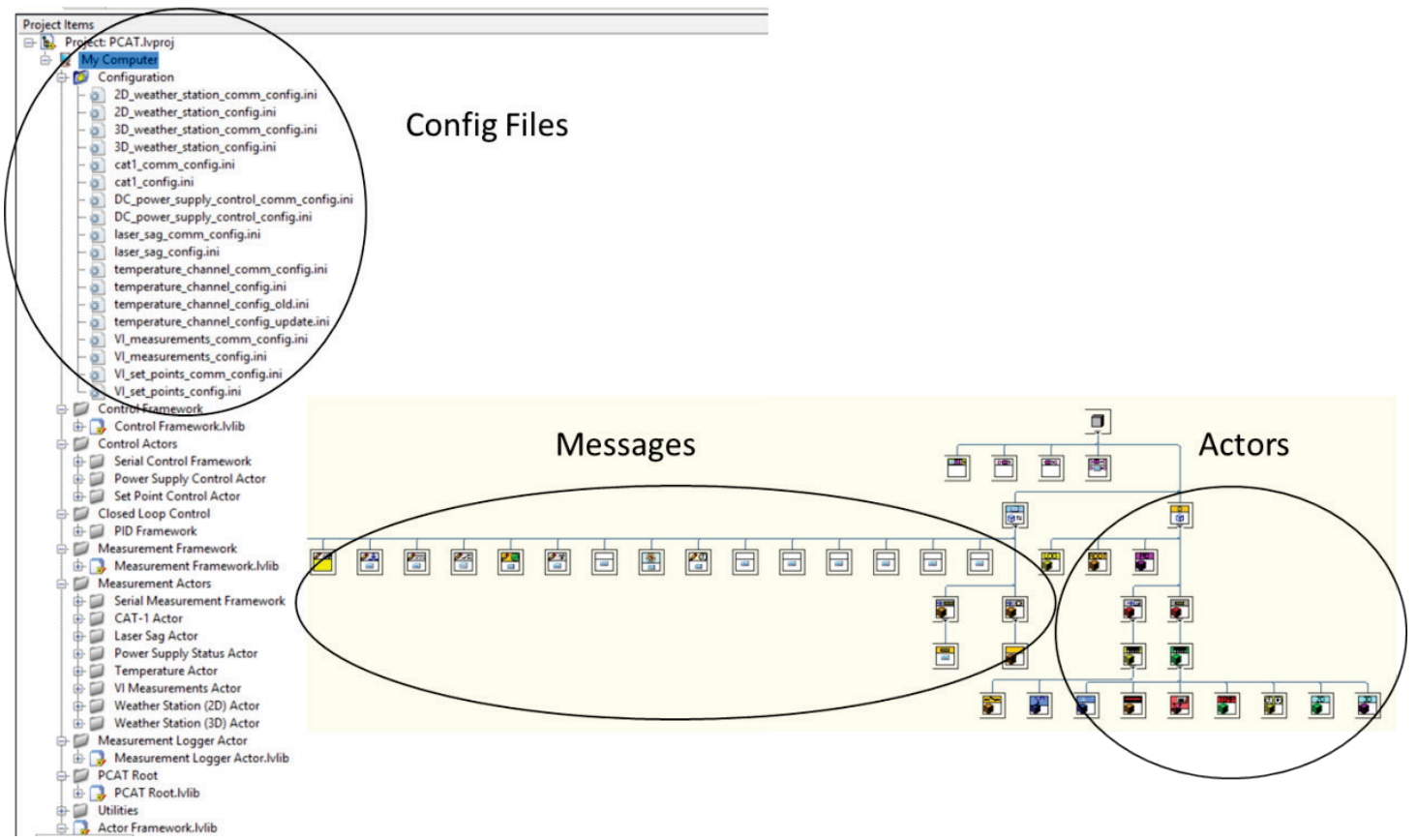

Fig. A.2. Proposed design for new LabVIEW-based system.

This transition will be accompanied by installation of additional sensors and a thermal camera for realtime images of ongoing tests. This will also include the addition of image processing to gain additional insight into the temperature and sag of conductors. 


\section{APPENDIX B. THERMOCOUPLE CHANNELS AND LOCATIONS}

Table B.1. Thermocouple Attachment Channels and Locations

\begin{tabular}{|c|c|c|c|c|c|}
\hline Channel & Location & Conductor & Channel & Location & Conductor \\
\hline $2-1 \mathrm{~T}$ & First Tower & Standard & $11-1 \mathrm{~T}$ & $750 \mathrm{ft}$ & Standard \\
\hline $2-2 \mathrm{~T}$ & First Tower & Standard & $11-2 \mathrm{~T}$ & $750 \mathrm{ft}$ & Standard \\
\hline $2-3 R$ & First Tower & $\mathrm{E} 3 \mathrm{X}$ & $11-3 R$ & $750 \mathrm{ft}$ & $\mathrm{E} 3 \mathrm{X}$ \\
\hline $2-4 \mathrm{R}$ & First Tower & E3X & $11-4 R$ & $750 \mathrm{ft}$ & E3X \\
\hline $3-1 \mathrm{~T}$ & First Tower & Standard & $12-1 \mathrm{~T}$ & $900 \mathrm{ft}$ (midspan) & Standard \\
\hline $3-2 \mathrm{~T}$ & First Tower & Standard & $12-2 \mathrm{~T}$ & $900 \mathrm{ft}$ (midspan) & Standard \\
\hline $3-3 R$ & First Tower & E3X & $12-3 R$ & $900 \mathrm{ft}$ (midspan) & E3X \\
\hline $3-4 R$ & First Tower & E3X & $12-4 R$ & $900 \mathrm{ft}$ (midspan) & E3X \\
\hline $5-1 \mathrm{~T}$ & $150 \mathrm{ft}$ & Standard & $13-1 \mathrm{~T}$ & $900 \mathrm{ft}$ (midspan) & Standard \\
\hline $5-2 \mathrm{~T}$ & $150 \mathrm{ft}$ & Standard & $13-2 \mathrm{~T}$ & $900 \mathrm{ft}$ (midspan) & Standard \\
\hline $5-3 R$ & $150 \mathrm{ft}$ & E3X & $13-3 R$ & $900 \mathrm{ft}$ (midspan) & E3X \\
\hline $5-4 \mathrm{R}$ & $150 \mathrm{ft}$ & E3X & $13-4 R$ & $900 \mathrm{ft}$ (midspan) & E3X \\
\hline $6-1 \mathrm{~T}$ & $300 \mathrm{ft}$ (midspan) & Standard & $14-1 \mathrm{~T}$ & $1050 \mathrm{ft}$ & Standard \\
\hline $6-2 \mathrm{~T}$ & $300 \mathrm{ft}$ (midspan) & Standard & $14-2 \mathrm{~T}$ & $1050 \mathrm{ft}$ & Standard \\
\hline $6-3 R$ & $300 \mathrm{ft}$ (midspan) & E3X & $14-3 R$ & $1050 \mathrm{ft}$ & E3X \\
\hline $6-4 R$ & $300 \mathrm{ft}$ (midspan) & E3X & $14-4 R$ & $1050 \mathrm{ft}$ & E3X \\
\hline $7-1 \mathrm{~T}$ & $300 \mathrm{ft}$ (midspan) & Standard & $15-5 \mathrm{~T}$ & Third Tower & Standard \\
\hline $7-2 \mathrm{~T}$ & $300 \mathrm{ft}$ (midspan) & Standard & $15-6 \mathrm{~T}$ & Third Tower & Standard \\
\hline $7-3 R$ & $300 \mathrm{ft}$ (midspan) & E3X & $15-7 \mathrm{R}$ & Third Tower & E3X \\
\hline $7-4 \mathrm{R}$ & $300 \mathrm{ft}$ (midspan) & E3X & $15-8 \mathrm{R}$ & Third Tower & E3X \\
\hline $8-1 \mathrm{~T}$ & $450 \mathrm{ft}$ & Standard & $16-5 \mathrm{~T}$ & Third Tower & Standard \\
\hline $8-2 \mathrm{~T}$ & $450 \mathrm{ft}$ & Standard & $16-6 \mathrm{~T}$ & Third Tower & Standard \\
\hline $8-3 R$ & $450 \mathrm{ft}$ & $\mathrm{E} 3 \mathrm{X}$ & $16-7 \mathrm{R}$ & Third Tower & E3X \\
\hline $8-4 \mathrm{R}$ & $450 \mathrm{ft}$ & E3X & $16-8 \mathrm{R}$ & Third Tower & E3X \\
\hline $10-1 \mathrm{~T}$ & Second Tower & Standard & & & \\
\hline $10-2 \mathrm{~T}$ & Second Tower & Standard & & & \\
\hline $10-3 R$ & Second Tower & E3X & & & \\
\hline $10-4 R$ & Second Tower & E3X & & & \\
\hline
\end{tabular}

Standard $=$ Drake/ACSS/MA2; E3X $=$ Drake/ACSS/MA2/E3X. 
